\title{
Testing for EGFR Mutations and ALK Rearrangements in Advanced Non-Small-Cell Lung Cancer: Considerations for Countries in Emerging Markets
}

\author{
Mercedes L Dalurzo (iD) ${ }^{1, *}$ \\ Alejandro Avilés-Salas (iD ${ }^{2, *}$ \\ Fernando Augusto Soares (D) ${ }^{3, *}$ \\ Yingyong $\mathrm{Hou}\left(\mathrm{DD}^{4, *}\right.$ \\ Yuan Li (iD) ${ }^{5, *}$ \\ Anna Stroganova (iD) ${ }^{6, *}$ \\ Büge Öz (iD ${ }^{7} *$ \\ Arif Abdillah iD ${ }^{8, *}$ \\ Hui Wan ${ }^{8, *}$ \\ Yoon-La Choi (iD) ${ }^{9, *}$ \\ 'Department of Pathology, Hospital Italiano de \\ Buenos Aires, Buenos Aires, Argentina; \\ ${ }^{2}$ Department of Pathology, Instituto Nacional \\ de Cancerología, Mexico City, Mexico; \\ ${ }^{3}$ Department of Pathology, A.C. Camargo \\ Cancer Center, São Paulo, Brazil; ${ }^{4}$ Department \\ of Pathology, Zhongshan Hospital, Fudan \\ University, Shanghai, People's Republic of \\ China; ${ }^{5}$ Department of Pathology, Fudan \\ University Shanghai Cancer Center, Shanghai, \\ People's Republic of China; ${ }^{6}$ N.N. Blokhin \\ National Medical Research Centre of \\ Oncology, Russian Academy of Medical \\ Sciences, Moscow, Russia; ${ }^{7}$ Cerrahpașa School \\ of Medicine, Istanbul University-Cerrahpașa, \\ Istanbul, Turkey; ${ }^{8}$ Takeda Pharmaceuticals \\ International AG - Singapore Branch, \\ Singapore, Singapore; ${ }^{9}$ Department of \\ Pathology and Translational Genomics, \\ Samsung Medical Centre, Sungkyunkwan \\ University School of Medicine, Seoul, South \\ Korea \\ *These authors contributed equally to this \\ work
}

Correspondence: Yoon-La Choi

Department of Pathology and

Translational Genomics, Samsung Medical

Centre, Sungkyunkwan University School

of Medicine, 8I, Irwon-ro, Gangnam-gu,

Seoul, 0635I, South Korea

Tel +82 234102797

Fax +82 234106396

Email ylachoi@skku.edu

\begin{abstract}
The treatment of patients with advanced non-small-cell lung cancer (NSCLC) in recent years has been increasingly guided by biomarker testing. Testing has centered on driver genetic alterations involving the epidermal growth factor receptor $(E G F R)$ and anaplastic lymphoma kinase $(A L K)$ rearrangements. The presence of these mutations is predictive of response to targeted therapies such as EGFR tyrosine kinase inhibitors (TKIs) and ALK TKIs. However, there are substantial challenges for the implementation of biomarker testing, particularly in emerging countries. Understanding the barriers to testing in NSCLC will be key to improving molecular testing rates worldwide and patient outcomes as a result. In this article, we review EGFR mutations and $A L K$ rearrangements as predictive biomarkers for NSCLC, discuss a selection of appropriate tests and review the literature with respect to the global uptake of $E G F R$ and $A L K$ testing. To help improve testing rates and unify procedures, we review our experiences with biomarker testing in China, South Korea, Russia, Turkey, Brazil, Argentina and Mexico, and propose a set of recommendations that pathologists from emerging countries can apply to assist with the diagnosis of NSCLC.
\end{abstract}

Keywords: non-small-cell lung cancer, EGFR testing, $A L K$ testing, immunohistochemistry, FISH, next-generation sequencing

\section{Introduction}

Lung cancer continues to be the leading cause of cancer mortality worldwide due to late diagnoses and limited treatment interventions. ${ }^{1-3}$ In 2020, lung cancer accounted for $11.4 \%$ of all newly diagnosed cancers (approximately 2.2 million) and was responsible for an estimated 1.8 million deaths $(18 \%$ of all cancer-related deaths). ${ }^{4}$ Despite ongoing small declines in lung cancer-related mortality in industrialized nations, such as the United States (US) and the United Kingdom (UK), mortality rates continue to rise in emerging nations, including Brazil, Russia, China, South Korea and Turkey. ${ }^{2}$ The reasons for these patterns are complex and multifactorial but include cigarette smoking, unequal access to healthcare leading to delayed diagnosis and treatment, environmental contamination and sociocultural barriers. $^{5}$

Non-small-cell lung cancer (NSCLC) accounts for $85 \%$ of all lung cancers and is a histologically and genetically heterogeneous disease. ${ }^{6}$ NSCLC includes two major types: (1) non-squamous cell carcinoma (non-SCC), including adenocarcinoma 
(AdC), large-cell carcinoma and other subtypes; and (2) squamous cell carcinoma (SCC). SCC was the most frequent histological subtype until the 1980s, when it was superseded by AdC, probably due to the introduction of cigarette filters and the rising number of women with lung cancer, who tend to be mostly affected by AdC. ${ }^{7,8}$ In the past decade, significant advances have been made in understanding the molecular profiles of lung cancer, and the identification of specific disease characteristics has paved the way for targeted therapies for neoplasms harboring oncogenic driver mutations or gene rearrangements. ${ }^{9}$

\section{Biomarker Testing for NSCLC}

Several biomarkers predictive of therapeutic efficacy have emerged for NSCLC, including epidermal growth factor receptor $(E G F R)$ mutations, alterations in the anaplastic lymphoma kinase $(A L K)$ gene, ROS1 rearrangements, BRAF V600E point mutations and programmed cell death ligand-1 (PD-L1) expression levels. ${ }^{10}$ The most established of these are EGFR mutations ${ }^{11}$ and $A L K$ rearrangements. ${ }^{12,13}$ This review only focuses on the prognostic role of these two biomarkers in NSCLC and the challenges in global uptake of EGFR and $A L K$ testing, especially in emerging markets. Other biomarkers are beyond the scope of this review.

In patients who harbor these biomarkers, targeted therapies with EGFR tyrosine kinase inhibitors (TKIs) and ALK inhibitors are now standard treatment, based on dramatic improvements observed in clinical trials. ${ }^{10,14,15}$ In recent studies of ALK inhibitors (eg alectinib, brigatinib, ceritinib, and lorlatinib), tumors were demonstrated to respond positively to treatment. These newer ALK inhibitors offer greater potency against resistance mutations to crizotinib and improved central nervous system (CNS) penetration, which is crucial in the treatment of $A L K$ positive brain metastases. ${ }^{16}$

Similarly, first-line therapy with an EGFR TKI (eg erlotinib, gefitinib and afatinib) significantly prolongs progression-free survival (PFS) and is associated with a significantly higher tumor response rate than first-line standard chemotherapy for patients with EGFR exon 18 to 21 mutations. In general, patients with activating mutations, such as exon 19 deletions and exon 21 mutations (L858R), are more responsive to TKIs. Conversely, acquired resistance mutations, such as the exon 20 T790M substitution, which is detected using circulating tumor DNA (ctDNA), ${ }^{17}$ is associated with poorer response to TKIs and disease progression within the first year of
TKI treatment. ${ }^{18}$ Osimertinib is a recent EGFR TKI which was developed in response to the resistant exon $20 \mathrm{~T} 790 \mathrm{M}$ substitution. ${ }^{19}$ Unlike newer EGFR TKIs that target specific mutations, older EGFR TKIs are less effective in treating emerging mutations, such as EGFR exon 20 insertions (ex20ins). ${ }^{20}$

Given the potential benefits of targeted therapy, timely and accurate classification of NSCLC subtypes has become fundamental in patients with advanced NSCLC. Indeed, most international guidelines recommend that all patients with advanced-stage non-SCC NSCLC should be tested for both EGFR mutations and $A L K$ rearrangements before initiation of first-line treatment, with a maximum turnaround time (TAT) of 10 working days. ${ }^{10,14,15}$ Despite this, diagnostic testing for predictive biomarkers in patients with NSCLC requires substantial resources and effort, and implementation of guideline recommendations in routine practice is not always applicable, especially in emerging countries where local health policies, drug approval, reimbursement issues, logistical constraints and lack of awareness can result in barriers to testing. The objective of this article is to review EGFR mutations and $A L K$ rearrangements as predictive biomarkers for NSCLC diagnosis, discuss a selection of appropriate tests for these biomarkers and identify trends in the uptake of molecular testing for $E G F R$ mutations and $A L K$ rearrangements in both developed and emerging countries. Finally, we review our experiences in China, South Korea, Russia, Turkey, Brazil, Argentina and Mexico, and propose a set of recommendations that pathologists from emerging countries can apply to implement effective biomarker testing to assist with the diagnosis of NSCLC.

\section{EGFR Mutations and ALK Rearrangements in Advanced NSCLC}

EGFR mutations and $A L K$ rearrangements are involved in NSCLC pathogenesis by stimulation of downstream signal transduction that leads to cell proliferation and inhibition of apoptosis. ${ }^{21,22}$ TKIs act by blocking cross-phosphorylation, leading to reduced activity of intracellular signaling pathways and cell proliferation. ${ }^{22,23}$ Historically, EGFR mutations and $A L K$ rearrangements were thought to be mutually exclusive. ${ }^{24}$ However, several recent reports have described these events occur concomitantly in 0.1$2.4 \%$ of patients with NSCLC. ${ }^{25-30}$ Cases with alterations 
of two oncogenic drivers remain rare, and the best management approach is still unclear.

\section{EGFR Mutations}

The most common EGFR mutations in patients with NSCLC are deletions in exon 19 (Exon 19del in $45 \%$ of all patients with EGFR mutations) and a point mutation in exon 21 (L858R in 40\% of all patients). ${ }^{14,31}$ Because the presence of EGFR exon 19 deletions or exon 21 L858R mutations is predictive of treatment benefit from EGFR TKI therapy, these mutations are referred to as sensitizing $E G F R$ mutations. Current guidelines suggest that patients without sensitizing EGFR mutations should not be treated with EGFR TKIs in any line of therapy. ${ }^{10,14}$ Exon 18 and 20 insertion mutations are less common and comprise the remaining $10 \%$ of EGFR mutants in NSCLC. ${ }^{31}$ The exon 20 T790M point mutation, and most EGFR ex20ins mutations, are predictive of treatment resistance to first- and second-generation EGFR TKI therapies. ${ }^{14,19}$

Designed in response to acquired T790M resistance, osimertinib is a third-generation EGFR TKI that irreversibly binds to the tyrosine kinase domain with lower toxicity than second-generation EGFR TKIs. ${ }^{19}$ Osimertinib has demonstrated significant activity in salvage treatment of T790M-positive Japanese patients ( $\mathrm{n}=147)$, with an objective response rate (ORR) and median PFS of $55.6 \%$ and 17.2 months, respectively. ${ }^{32}$ Using osimertinib to treat patients with EGFR ex20ins has yielded inconclusive efficacy results. A retrospective study reported an ORR of $5 \%$ and median PFS of 3.6 months, ${ }^{33}$ whereas a Phase II study (where osimertinib was administered at double the approved dose) reported an ORR of $24 \%$ and median PFS of 9.6 months. $^{34}$

Recently, the FDA granted approval for amivantamab, ${ }^{35}$ a novel bispecific EGFR-MET antibody, administered via intravenous infusion for the treatment of patients with EGFR ex20ins NSCLC whose disease has progressed during or after treatment with platinum-based chemotherapy. Amivantamab showed an ORR of $36 \%$ per investigator assessment (IA) and 40\% per independent review committee (IRC). Both IA and IRC assessments for median PFS were 8.3 months, median overall survival (OS) was 22.8 months and median duration of response per IRC was 11.1 months. ${ }^{36,37}$ Other emerging treatments such as mobocertinib, an oral EGFR TKI with selective activity against $E G F R$ ex20ins, demonstrated rapid and durable responses in platinum-pretreated patients with EGFR ex20ins metastatic NSCLC. In these patients, an ORR of $28 \%$, median PFS of 7.3 months, median OS of 24.0 months and median duration of response of 17.5 months, according to IRC assessment, were reported. ${ }^{38,39}$

The overall prevalence of sensitizing EGFR mutations varies significantly according to ethnicity. ${ }^{11,40-46}$ Recently, Graham et al determined the frequency of sensitizing EGFR mutations detected in 170 clinical laboratories from 20 countries participating in the College of American Pathologists (CAP) proficiency testing program. $^{43}$ The highest activating EGFR mutation frequency was seen in southern Asia (4260/9337; 46\%), and the lowest mutation frequencies in South and North America (113/1439; 8\% and 7926/86,654; 9\%, respectively) among patients tested for EGFR. However, interpretation of survey-led data should be treated with caution, as the information provided is limited to participating centers only. ${ }^{43}$ For example, the frequency reported for South America in the study by Graham et al only examined cases in Brazil, ${ }^{43}$ while another dedicated study of EGFR mutations in 5738 patients with NSCLC in Latin America that included Argentina, Mexico, Colombia, Peru, Panama and Costa Rica, reported a frequency of $26 \%$ - a rate between that observed in Asian (40\%) and Caucasian populations (15\%). ${ }^{47}$ Similarly, a US-based cancer registry study (2009-2015) reported a higher frequency of $E G F R$ mutations in black (35/98, 35.7\%), and non-black patients $(63 / 98,64.2 \%)$ compared with figures observed by Graham et al highlighting the limitations of a small patient population. ${ }^{43,46}$ Interestingly, Cheng et al reported significantly shorter survival outcomes among black patients presenting with EGFR mutations, with 2year survival rates almost half those of non-black patients $(\mathrm{p}=0.001)$. No racial disparity in survival was observed among patients with wild-type $E G F R$ ( $\mathrm{p}=0.774)$, suggesting the need for improved, tailored management in this patient population. ${ }^{46}$

In general, patients with sensitizing EGFR mutations are more likely to be non-smokers or former light smokers with AdC histology. However, these characteristics alone should not be used for selecting patients for $E G F R$ testing. ${ }^{14}$

Most patients with EGFR sensitizing mutations treated with first- and second-generation TKI therapy experience disease progression after approximately 12 months. ${ }^{48,49} \mathrm{~A}$ variety of mechanisms are involved in acquired resistance to EGFR TKIs; however, an estimated 50-60\% of cases can be attributed to the EGFR T790M exon 20 substitution mutation. $^{48,49}$ Sensitive assays have detected the T790M 
mutation in patients prior to initiation of a first-generation TKI. This shows T790M could also be a de novo mutation and provides one explanation for intrinsic resistance. ${ }^{50-53}$ It is critical to detect this mutation in patients who have developed acquired resistance against first- or second-line EGFR TKIs, as third-generation EGFR TKIs can effectively target T790M-positive cancers. ${ }^{54-58}$ Observational medical record data from the US $(n=308)$ suggest that $80 \%$ of patients receive a first-line TKI-based treatment with or without combination chemotherapy for EGFR-positive Stage IV NSCLC. Only $26 \%$ of patients received TKI therapy in the second line, whereas over half of patients stopped first-line TKI and presented no subsequent treatment record. ${ }^{59}$

\section{ALK Rearrangements}

In NSCLC, the $A L K$ gene rearrangement results in a fusion protein containing a dysregulated, constitutively active $A L K$ kinase domain. ${ }^{24,60-64}$ Although evidence of $A L K$ rearrangement is present in only $2-12 \%$ of all NSCLC cases, ${ }^{42,65-67}$ approximately $60 \%$ of patients will respond to targeted ALK inhibition ${ }^{17}$ using therapies such as alectinib, brigatinib, ceritinib, crizotinib and lorlatinib. ${ }^{68-74}$ Clinical characteristics associated with the $A L K$ gene rearrangement include $\mathrm{AdC}$ histology, never-/light-smoking history and younger age. ${ }^{71,75-77}$ However, these characteristics alone should not be used to determine the need for $A L K$ testing; $A L K$ fusion has also been detected in older patients ( $>70$ years of age) with a smoking history and in patients with SCC. ${ }^{78,79}$

\section{Testing for EGFR Mutations and ALK Rearrangements}

There is general consensus among international guidelines (National Comprehensive Cancer Network [NCCN], European Society for Medical Oncology [ESMO], CAP, International Association for the Study of Lung Cancer [IASLC], Association for Molecular Pathology [AMP]) that all patients with advanced non-SCC NSCLC, regardless of clinical characteristics (such as age, race or smoking status, and including some patients with SCC, such as non-smokers or those $<40$ years of age), should undergo, at a minimum, testing for EGFR mutation, $A L K$ and ROS1 rearrangements, $B R A F$ mutation and $P D-L 1$ expression. Moreover, if next-generation sequencing (NGS) is available, additional alterations in genes such as RET, MET, HER2 and KRAS should also be assessed. ${ }^{10,14,15,80,81}$
In practice, $E G F R$ and $A L K$ testing is usually performed upon request by the medical oncologist. However, several consensus statements and local policies advocate reflex molecular testing (by pathologists) upon diagnosis of non-SCC NSCLC, regardless of clinical stage. ${ }^{82,83}$ This policy has been shown to increase the rate of molecular testing by approximately one-third in some settings ${ }^{84}$ and reduce the time to initiating treatment. ${ }^{82,85}$ In a recent study from Toronto, Canada, Cheema et al compared outcomes during routine and reflex biomarker testing among 306 patients with newly diagnosed NSCLC. Reflex $E G F R / A L K$ testing was associated with a significant improvement in time to optimal systemic therapy, as defined by published guidelines (from 36 to 24 days). ${ }^{82}$

\section{EGFR Testing}

Advanced polymerase chain reaction (PCR)-based methods, such as amplified refractory mutation system (ARMS)-PCR, real-time or quantitative PCR (qPCR), reverse transcriptase PCR (RT-PCR), Sanger sequencing (ideally paired with tumor enrichment) and NGS are the most common methodologies for examining EGFR mutation status (Tables 1 and 2). ${ }^{14,17}$ Guidelines issued by CAP, IASLC and AMP strongly recommend against using total EGFR expression by immunohistochemistry (IHC) testing to select patients for EGFR-targeted TKI therapy. ${ }^{81}$

The gold standard for analyzing mutations is direct sequencing. However, direct DNA sequencing without a mutation enrichment step has a lower limit of detection of $10-25 \%$ of total DNA, meaning that the use of samples with low tumor cellularity can result in false-negative outcomes. ${ }^{86}$ In contrast, qPCR-based methods show high sensitivity, and testing can be performed relatively quickly on small quantities of tissue (eg one day on average for one sample). ${ }^{81,87}$ FDA-approved companion diagnostic tests (CDx) include the Roche Cobas ${ }^{\circledR}$ EGFR Mutation test V2 (a real-time PCR test for erlotinib and osimertinib) and the Qiagen therascreen EGFR rotor-gene Q (RGQ) PCR kit (for gefitinib and afatinib) (Table 3). ${ }^{88,89}$ However, several studies have shown that commercially available PCR kits may not detect $50 \%$ or more of the patients with ex20ins NSCLC identified by $\mathrm{NGS}^{89-92}$ and may only detect known or a limited number of mutations. ${ }^{93,94}$ This could mostly be due to the design of the primers in the PCR kits. ${ }^{95}$ This suggests NGS has greater sensitivity than PCR in detecting EGFR mutations. ${ }^{96}$ However, newer PCR kits are designed to overcome this limitation and increase 
Table I Mutation-Detection Assays (Eg EGFR, BRAF)

\begin{tabular}{|c|c|c|}
\hline Assay & Advantage & Disadvantage \\
\hline $\begin{array}{l}\text { Sanger sequencing } \\
\text { (direct DNA } \\
\text { sequencing) }\end{array}$ & $\begin{array}{l}\text { - Identification of all known and previously unknown mutations } \\
\text { within the studied region }\end{array}$ & $\begin{array}{l}\text { - High tumor content required (mutation detected } \\
\text { when allele frequency }>25 \% \text { total DNA [50\% } \\
\text { tumor content]) } \\
\text { - Low sensitivity }\end{array}$ \\
\hline $\begin{array}{l}\text { Allele-specific real- } \\
\text { time PCR (targeted } \\
\text { assays) }\end{array}$ & $\begin{array}{l}\text { - Allows rapid multiplex genotyping of specific known hotspot } \\
\text { mutations } \\
\text { - More sensitive than Sanger (requires } 5-10 \% \text { of the starting } \\
\text { tumor DNA) }\end{array}$ & $\begin{array}{l}\text { - Designed only to detect most frequent mutations } \\
\text { - Unable to detect mutations different from those } \\
\text { included in the assay (low frequency or novel } \\
\text { mutations) }\end{array}$ \\
\hline $\begin{array}{l}\text { NGS (massive } \\
\text { parallel sequencing } \\
\text { technology) }\end{array}$ & $\begin{array}{l}\text { - Detection of multiple genetic alterations (mutations, gene } \\
\text { fusions, CNV), allowing the sequencing of large regions of the } \\
\text { genome with higher sensitivity } \\
\text { - Can be performed by FFPE extraction and freshly collected } \\
\text { tissue specimens }\end{array}$ & $\begin{array}{l}\text { - Effective implementation of NGS requires good- } \\
\text { quality DNA and RNA (not always present in } \\
\text { FFPE samples) } \\
\text { - Validation of panels can be expensive and difficult } \\
\text { for some laboratories in low- or mid-income } \\
\text { countries }\end{array}$ \\
\hline
\end{tabular}

Note: Data from Mok et al..$^{98}$

Abbreviations: CNV, copy-number variation; FFPE, formalin-fixed paraffin-embedded; NGS, next-generation sequencing; PCR, polymerase chain reaction; TAT, turnaround time.

Table 2 Rearrangement-Detection Assays (Eg ALK, ROSI Fusion)

\begin{tabular}{|c|c|c|}
\hline Assay & Advantage & Disadvantage \\
\hline $\begin{array}{l}\text { RT- } \\
\text { PCR }\end{array}$ & $\begin{array}{l}\text { - High sensitivity } \\
\text { - High specificity } \\
\text { - Can be used on mRNA/cDNA to directly detect fusion genes }\end{array}$ & $\begin{array}{l}\text { - Not applicable for unknown partners } \\
\text { - High-quality of RNA is required (difficult to apply in } \\
\text { long-term stored tissue and FFPE samples) } \\
\text { - Multiplexed assays are required to cover the large } \\
\text { variety of fusion transcripts }{ }^{185,186}\end{array}$ \\
\hline FISH & $\begin{array}{l}\text { - Sensitive and specific } \\
\text { - Detects fusions irrespective of the fusion partner } \\
\text { - Break Apart assay Vysis CDx was established as a 'gold standard' to } \\
\text { detect ALK fusion in NSCLC } \\
\text { - Allows use of archived FFPE tissue samples and all cytology samples }\end{array}$ & $\begin{array}{l}\text { - Unable to identify the specific gene fusion partner } \\
\text { - Interpretation requires specialized training } \\
\text { - The 'break apart' can be difficult to identify due to } \\
\text { small physical separation of ALK or ROSI fragments } \\
\text { - Testing is relatively costly and time-consuming } \\
\text { - Samples may not contain enough assessable cells to } \\
\text { be properly interpreted } \\
\text { - The } 15 \% \text { cutoff and potential false-positive and false- } \\
\text { negative signaling profiles may challenge } \\
\text { interpretation }\end{array}$ \\
\hline $\mathrm{IHC}$ & $\begin{array}{l}\text { - Widely available, relatively inexpensive } \\
\text { - Rapid TAT } \\
\text { - For ALK rearrangement, IHC is valid with any quantity and percentage of } \\
\text { positive tumor cells (useful in biopsy) or cytology samples with a small } \\
\text { amount of tumor cells }{ }^{190,191}\end{array}$ & $\begin{array}{l}\text { - ROSI-positive IHC requires confirmation by FISH } \\
(\geq I 5 \% \text { tumor cells) } \\
\text { - LDT IHC tests require careful validation }\end{array}$ \\
\hline NGS & $\begin{array}{l}\text { - Same advantages as detailed for mutation studies } \\
\text { - There are some commercial lung cancer-specific fusion panels }{ }^{153,192}\end{array}$ & $\begin{array}{l}\text { - Same disadvantages as detailed for mutation studies } \\
\text { - Good quality RNA is required }\end{array}$ \\
\hline
\end{tabular}

Note: Data from Tsao et al. ${ }^{105}$

Abbreviations: ALK, anaplastic lymphoma kinase; cDNA, circulating DNA; CDx, companion diagnostic test; FFPE, formalin-fixed paraffin-embedded; FISH, fluorescence in situ hybridization; IHC, immunohistochemistry; LDT, laboratory-developed test; mRNA, messenger RNA; NGS, next-generation sequencing; NSCLC, non-small-cell lung cancer; RT PCR, reverse transcriptase polymerase chain reaction; TAT, turnaround time. 
Table 3 US FDA-Approved Drugs and Companion Diagnostics for Advanced NSCLC

\begin{tabular}{|c|l|}
\hline Targeted Agent & Companion Diagnostic Test \\
\hline EGFR & \\
\hline \multicolumn{1}{|l|}{$\begin{array}{l}\text { Erlotinib } \\
\text { Gefitinib } \\
\text { Afatinib } \\
\text { Osimertinib }\end{array}$} & $\begin{array}{l}\text { Cobas }{ }^{\circledR} \text { EGFR Mutation Test v2 } \\
\text { Therascreen EGFR RGQ PCR Kit } \\
\text { Therascreen EGFR RGQ PCR Kit } \\
\text { Cobas }{ }^{\circledR} \text { EGFR Mutation Test v2 }\end{array}$ \\
\hline ALK & \\
\hline $\begin{array}{l}\text { Crizotinib } \\
\text { Ceritinib } \\
\text { Alectinib } \\
\text { Lorlatinib }\end{array}$ & Vysis ALK Break Apart FISH Probe Kit \\
\hline
\end{tabular}

Note: Adapted with permission from Schwartzberg L, Kim ES, Liu D, Schrag D. Precision oncology: who, how, what, when, and when not? Am Soc Clin Oncol Educ Book. 2017;37:160-169 ${ }^{88}$ with data from these studies. ${ }^{106,193}$

Abbreviations: ALK, anaplastic lymphoma kinase; CDx, companion diagnostic test; EGFR, epidermal growth factor receptor; FDA, Food and Drug Administration; FISH, fluorescence in situ hybridization; NSCLC, non-small-cell lung cancer; PCR, polymerase chain reaction; RGQ, Rotor-Gene Q.

coverage of detection for EGFR mutations. ${ }^{95}$ For example, one Japanese study demonstrated the Amoy 9-in-1 qPCR test had high concordance with the Oncomine comprehensive assay 3.0 NGS test, with $99 \%$ overall agreement when detecting ex20ins. ${ }^{89}$ Pathologists should consider the available approaches and the advantages and disadvantages of each method, including analytical sensitivity and TAT. One testing platform is usually sufficient for EGFR testing. However, when the sample contains a small amount of DNA, testing for most frequent EGFR mutations, such as exon 19 deletions and L858R mutations, should be prioritized. $^{10,15,97}$

In the setting of active disease progression while exposed to targeted therapy, retesting a tumor sample can shed light on the next appropriate therapeutic steps. Liquid biopsy analysis of ctDNA has become the recommended approach for detecting EGFR T790M mutations. ${ }^{17}$ This technique assesses the release of DNA fragments from tumor cells into the peripheral circulation due to apoptosis and necrosis. ${ }^{17,98-100}$ Recent realworld data suggest droplet-digital PCR has high sensitivity and specificity for low-abundance T790M mutation. ${ }^{18}$ The NCCN and ESMO guidelines now recommend repeat genomic testing at progression to identify $E G F R$ - and $A L K$-resistance targets.${ }^{10,14}$ Newer applications for ctDNA, such as real-time therapy response monitoring, minimal residual disease (MRD) testing, and their use as a predictive biomarkers for immunotherapy, are currently under investigation. ${ }^{101,102}$ When there is no evidence of $E G F R$ T790M, testing for alternate mechanisms of resistance (eg $M E T$ amplification, ERBB2 amplification) may be used to direct patients to additional therapies. ${ }^{14}$

\section{ALK Testing}

Testing for $A L K$ rearrangement should be systematically carried out in all patients with advanced non-SCC NSCLC. ${ }^{10,15}$ There are currently three detection methods widely available in clinical practice, including fluorescence in situ hybridization (FISH), IHC and NGS technology. FISH is considered the 'gold standard' and the most widely used assay for $A L K$ rearrangement detection. $^{10,15}$ The FISH assay (Vysis LSI $A L K$ Break Apart Rearrangement Probe Kit; Abbott Molecular) is a US FDA-approved CDx for $A L K$ rearrangement detection for crizotinib, which received approval in 2011. ${ }^{103}$ The newer ALK inhibitors, alectinib, brigatinib, ceritinib, and lorlatinib are also paired with this diagnostic test. However, in recent years NGS testing has gained increased use for $A L K$ rearrangement detection, overtaking FISH testing (46.0\% compared with $37.7 \%$ ) in $2019 .{ }^{103}$

FISH has several limitations, including the need for expensive equipment, combined with technical and interpretative expertise. Lung cancer cells may overlap with normal lung tissue, and confidently distinguishing between the two in a dark field can be a challenge. Furthermore, appropriate long-term storage conditions that control for light, heat and humidity, are necessary to preserve tissue samples and reduce signal decay. ${ }^{104,105}$ The type of $A L K$ rearrangement can also affect the outcome of FISH testing, producing either falsenegative or false-positive results. Although the FISH assay has been firmly validated, the potential for false-negatives highlights the importance of combining more than one testing modality to achieve $100 \%$ accuracy with different $A L K$ rearrangements in NSCLC. ${ }^{104}$ Other limitations of FISH include the requirement of $\geq 50$ tumor cells for the determination of $A L K$ status. ${ }^{104}$

IHC testing is routinely used in diagnostic pathology labs for a variety of reasons, including determination of tumor lineage and subtype. Several antibodies are currently available that detect $A L K$ protein expression in NSCLC, using formalin-fixed paraffin-embedded (FFPE) tissue, including the mouse monoclonal antibody 5A4 (Abcam) and the rabbit monoclonal antibody D5F3 (Ventana Medical Systems Inc, Tucson, AZ, Cell Signaling Technology). In 2012, the Ventana ALK (D5F3) assay was approved in Europe as a CDx test to aid in the identification of $A L K$ rearrangement in patients 
with NSCLC. The assay was approved by the National Medical Products Administration (NMPA, formerly known as the Chinese Food and Drug Administration) in $2013^{104}$ and by the US FDA in $2015 .{ }^{106}$

There are technical challenges in detecting $A L K$ rearrangement effectively by IHC in a spectrum of tissue types. Therefore, it is important for positive/negative controls to ensure accurate interpretation of staining intensity without subjectivity. ${ }^{104}$ Until recently, there was considerable debate over testing algorithms for $A L K$ detection, and previous guidelines recommended that all $A L K$-IHC-positive results should be confirmed by $A L K$ FISH. ${ }^{107-109}$ However, given the cost-effectiveness and rapid TAT of IHC, combined with the accuracy of the technique when combined with high-performance antibodies, IHC is now considered to be an equivalent alternative to FISH for $A L K$ testing in patients with NSCLC. ${ }^{10,14,15,80,81}$

\section{Next-Generation Sequencing}

In response to the ever-growing list of predictive biomarkers, NGS technology has emerged as a preferred method for comprehensive testing in NSCLC. NGS enables the simultaneous assessment of many DNA or RNA alterations beyond $E G F R$ and $A L K$ that are rapidly becoming clinically relevant. Targeted testing provides higher coverage of genomic regions of interest to improve detection of relevant alterations and to allow critical molecular information to be available for therapeutic decisions in an adequate time frame. Performed in an optimized way, NGS can result in improved tissue use and efficiency. ${ }^{110,111}$ The US FDA recently approved two DNA-based NGS platforms for molecular testing in advanced malignancies: the Memorial Sloan Kettering-Integrated Mutation Profiling of Actionable Cancer Targets and FoundationOne CDx. ${ }^{112}$

DNA is more stable than RNA, and for many clinical purposes, DNA-based sequencing using panels of specific disease-related genes is sufficient. However, at the DNA level, it is not always possible to detect gene-fusion expression, particularly if breakpoints involve long intronic regions that cannot be covered by hybridization-capture probes. ${ }^{113}$ To address this issue, targeted RNA-based NGS assays have been developed for gene-fusion detection, and emerging evidence suggests that these platforms can be more sensitive, efficient and functionally definitive, considering that many DNA variants (eg multiple intronic breakpoints) give rise to the same oncogenic transcript. ${ }^{114-116}$ One potential drawback to this approach is that it requires good-quality RNA, which is sometimes difficult to obtain from FFPE specimens. ${ }^{99}$ Although RNA-based assays can be based on hybrid-capture or amplicon-based methods, most use the latter. ${ }^{99}$

\section{International Patterns of Biomarker Testing}

To better understand patterns of uptake for biomarker testing in advanced NSCLC, we searched the PubMed and Embase databases for articles published in English with abstracts between 01 January 2000 and 24 May 2021. Articles were selected by combining search results generated with exploded medical subject headings (MeSH) or keywords from the following categories: (1) NSCLC (ie non-small-cell lung cancer, carcinoma, nonsmall-cell lung, etc), (2) $A L K$ (ie anaplastic lymphoma kinase), (3) $E G F R$ (ie epidermal growth factor receptor) and (4) testing (ie molecular testing, molecular diagnosis, testing patterns, testing frequency, diagnostic testing, diagnostic patterns, etc). We hand-searched the reference lists of retrieved articles for additional studies. Abstracts only and/or conference proceedings were excluded.

We identified 24 articles incorporating data from 45 countries. Articles are presented in Table 4 according to region (to account for ethnic differences in molecular profiles) and in chronological order (eg oldest to most recent). Among the articles retrieved, 14 were retrospective reviews, ${ }^{42,117-129}$ eight were based on data from surveys and/or interviews with healthcare professionals, ${ }^{130-137}$ and two were observational studies. ${ }^{138,139}$

Despite general consensus that biomarker testing is necessary for patients with NSCLC, our review demonstrates this is not being translated into clinical practice, given that testing is highly variable. Although EGFR testing has been recognized as standard practice since 2011, the implementation of this assessment can still be inconsistent. However, biomarker testing for EGFR mutations and $A L K$ rearrangements appear to have increased in most regions over time. In the largest real-world assessment of $A L K$-testing patterns in patients with NSCLC from the US, $A L K$ testing rates increased over time from $32 \%$ in 2011 to $62 \%$ in $2016 .{ }^{119}$ Similarly, in a study from the Netherlands by Sluga et al the rate of performing molecular diagnostic testing for NSCLC increased from $11 \%$ in 2008 to $75 \%$ in 2014. ${ }^{127}$

Several international studies have also identified variable rates of testing between different countries. In the PiVOTAL study, a multinational retrospective study 


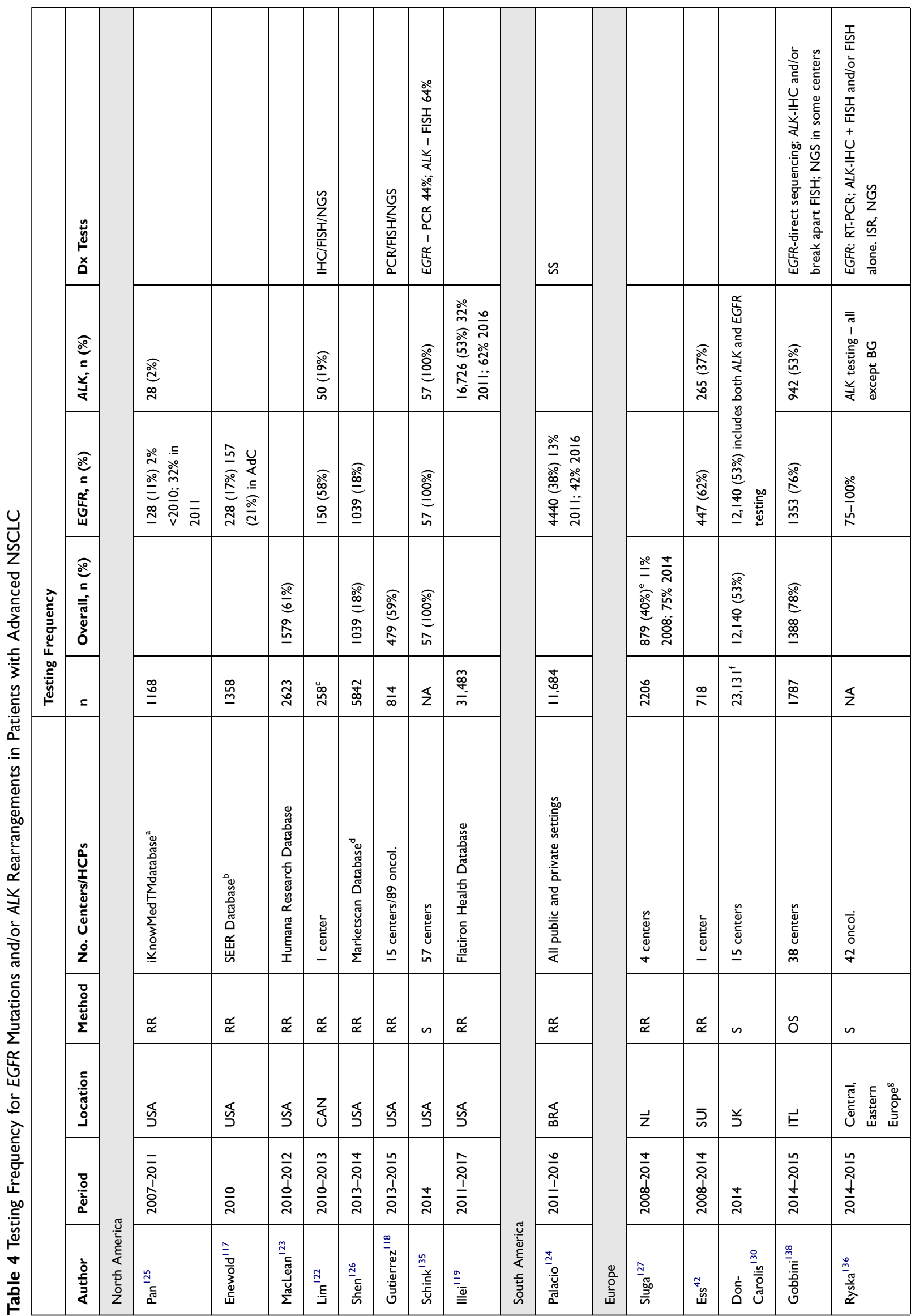




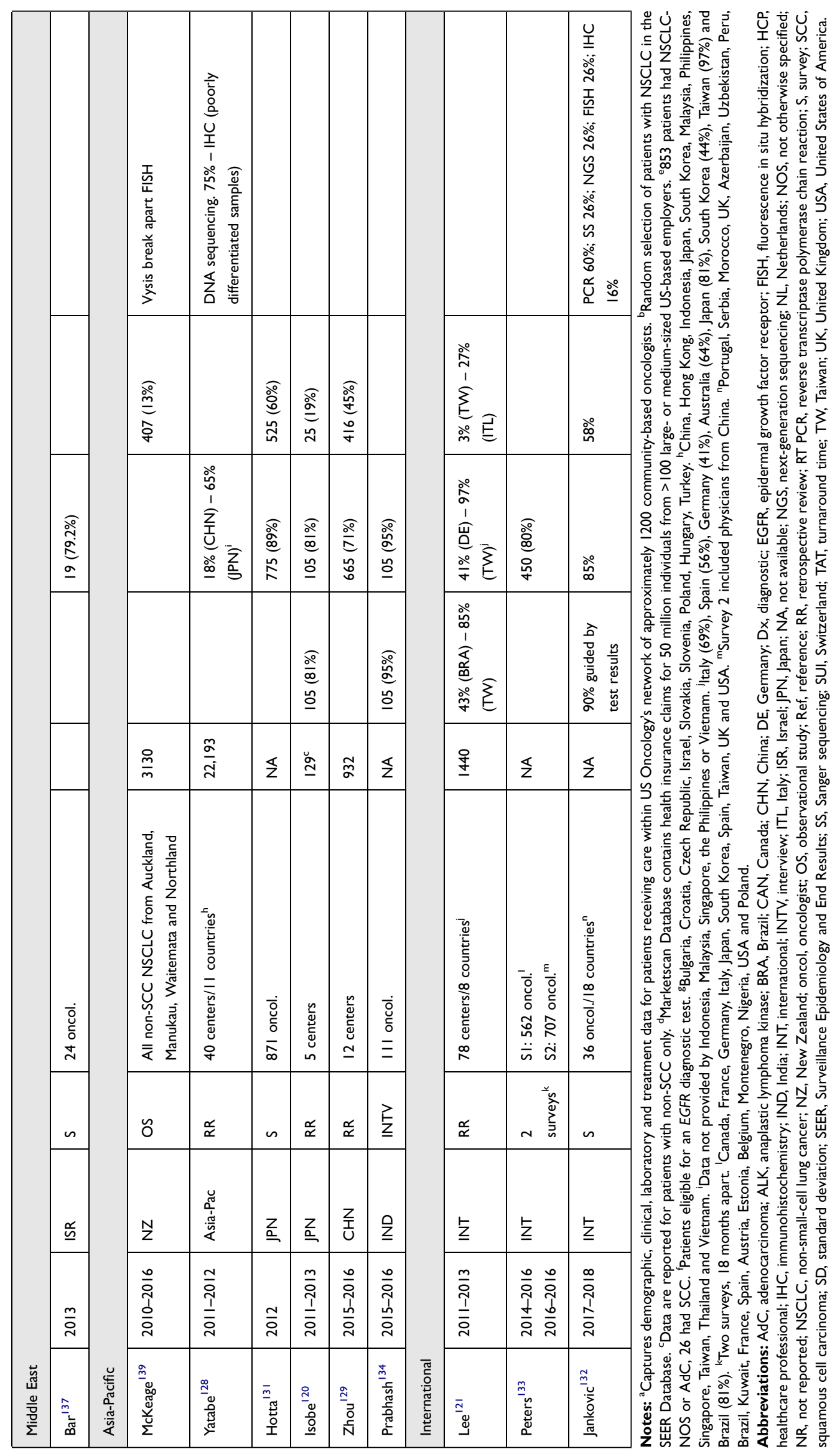


conducted in Italy, Spain, Germany, Australia, Japan, South Korea, Taiwan and Brazil, a total of 1440 patients with newly diagnosed advanced NSCLC were enrolled from 78 centers in eight countries. ${ }^{121}$ The EGFR testing rate ranged between $43 \%$ in Brazil to $85 \%$ in Taiwan. Molecular testing rates (non-specific to NGS/PCR) were similar in Spain, South Korea and Japan $(76 \%, 76 \%$ and $74 \%$, respectively). ${ }^{121}$ In the same study, the proportion of patients with $A L K$ testing ranged from $41 \%$ in Germany to $97 \%$ in Taiwan. ${ }^{121}$ In a more recent survey of oncologists from multiple developed countries, the proportion of physicians who requested $E G F R$ testing before first-line therapy was $80 \% .{ }^{133}$ In Asia, EGFR mutation testing was ordered before first-line therapy in $92 \%$ and $84 \%$ of patients in 2015 and 2016, respectively. In Europe, rates of $E G F R$ testing for the same periods were $77 \%$ and $81 \%$, whereas in North America, $76 \%$ of patients with advanced NSCLC were assessed for EGFR mutations in 2015 compared with $77 \%$ in $2016 .{ }^{133}$ A global survey by the IASLC of their members and allied healthcare professionals $(n=2537)$ across 102 countries suggested that fewer than $50 \%$ of patients received molecular testing. ${ }^{140}$ Many respondents expressed dissatisfaction with the current state of molecular testing in their country, including $41 \%$ of those performing and interpreting assays, with identified issues including difficulties in understanding results (37\%) and the quality of the samples (23\% reported a $>10 \%$ rejection rate). Despite concerns regarding the quality of testing, $47 \%$ of respondents involved in performing and interpreting assays stated there was no policy or strategy to improve quality in their country. ${ }^{140}$

Several studies reported survival differences between cohorts who were tested for molecular biomarkers and, if appropriate, received targeted therapy, versus those who never received a molecular test. In a study from Switzerland involving 718 patients, OS was 10 months (interquartile range [IQR] 4-23 months) for tested patients compared with 3 months (IQR 1-8 months) in patients who were not tested. ${ }^{42}$ Similarly, in the PiVOTAL study, patients who were tested had longer OS than patients who were not tested: the median OS from start of first-line therapy ranged from 10.0 (Japan) to 26.7 (Taiwan) months for patients who were tested, and 7.6 (Australia/Brazil) to 19.3 (Taiwan) months for those who were not. ${ }^{121}$ Additional studies have found that the probability of molecular testing varies according to practice (eg private versus public), ${ }^{124}$ de novo versus subsequent-line therapy, ${ }^{141}$ the degree of life expectancy ( $<1$ month versus $\geq 1$ month), ${ }^{42}$ patient age, ${ }^{126}$ rural versus urban practice, ${ }^{142}$ and the presence of $\geq 2$ comorbidities. ${ }^{42}$

Direct comparisons of testing uptake between regions should be treated with caution. The rate of biomarker testing uptake depends on many factors, not least of which is the availability of targeted therapies. For example, in the PiVOTAL study, Taiwan had the highest rate of biomarker testing (85\%), driven largely by the reimbursement of gefitinib. However, Brazil had the lowest testing rate $(43 \%)$, mainly because the necessary assays were not covered by the public healthcare system during the study period. ${ }^{121}$ Other possible explanations for the different rates of uptake may relate to higher detection rates for EGFR mutations in certain populations (eg Asia). Because many clinical trials demonstrating the superiority of EGFR TKIs over cytotoxic chemotherapy were conducted in Asia, it is reasonable to expect that the experience gained by clinicians and pathologists in those countries has led to more efficient diagnostic services and an increase in the likelihood of testing and treating patients with NSCLC in accordance with guidelines. ${ }^{133}$

\section{Barriers to Biomarker Testing}

Barriers to the uptake of biomarker testing are multifactorial and often country-specific. However, access to targeted therapies and absence of reimbursement for testing and/or availability of testing facilities are the main barriers cited in the literature (Table 5); ${ }^{120,121,132,136,138,139,143,144}$ assay quality and standards, awareness, and TAT have also been highlighted as additional hurdles to testing. ${ }^{140}$ As expected, testing for a specific driver mutation tends to be associated with access to the associated drug, ${ }^{121,143}$ and in general, targeted treatments are more accessible for clinicians in the US and Europe than for their colleagues in Africa, non-European countries and South America. ${ }^{132,144}$ On a similar note, limited and/or absent

Table 5 Potential Barriers to Biomarker Testing

\begin{tabular}{|c|}
\hline Access to targeted therapies ${ }^{118,135,137-139,143}$ \\
\hline Reimbursement for testing ${ }^{133,138}$ \\
\hline Tissue sample quality ${ }^{98,143}$ \\
\hline TAT for test results ${ }^{42,120,131}$ \\
\hline Coordination among multiple specialist groups $s^{126}$ \\
\hline Accurate interpretation of results/physician education 118 \\
\hline
\end{tabular}

Abbreviation: TAT, turnaround time. 
reimbursement is a significant barrier to biomarker testing and a disincentive to reflex testing. ${ }^{132,136,143}$ In an international survey of medical oncologists, $38 \%$ of respondents noted that biomarker tests were paid for by patients, whereas in $29 \%$ and $23 \%$ of cases, the expenses were covered by insurance or hospital funds, respectively. ${ }^{132}$ Another study of biomarker testing practices in Eastern European countries found that pharmaceutical sponsorship was necessary in order to subsidize the cost of testing in Hungary, Poland and Slovenia. Furthermore, the study reported that in Bulgaria and Croatia, pharmaceutical sponsorship was the only source of financial support for testing. ${ }^{136}$ In these situations, creative discussions with all interested parties are critical to finding new solutions. One potential strategy is the development of policies to promote access to testing by establishing links between health systems, and science and technology offices with active participation from the pharmaceutical industry. ${ }^{144}$

Use of validated models for estimating EGFR mutation status has been proposed for patients with non-SCC. ${ }^{145}$ Based on retrospective patient cohort data in New Zealand, logistical regression modeling of recognized risk factors (including sex, ethnicity, and smoking status) has enabled predictive mutation modeling that may assist clinical decision-making in patients where tissue-based mutation testing is difficult, or as a supplement to mutation testing. $^{145}$

Nonetheless, obtaining adequate tissue for diagnosis, tissue subtyping and molecular profiling are imperative for treatment planning in patients with advanced NSCLC. However, tissue samples from biopsies are often insufficient or inadequate for biomarker testing, ${ }^{86,122,133,136,146}$ necessitating repeat biopsies and delays in treatment. ${ }^{100}$ Optimizing tissue handling after biopsies are obtained to maximize available material for molecular studies is essential, and standardized algorithms for diagnostic procedures should be defined in routine practice. These should involve reflex testing for biomarker testing, which will shorten TAT and preserve tissue. ${ }^{135,147}$ Quality control is also essential to ensure internal reproducibility and the validity of biomarker results. All laboratories should be certified and participate regularly in established qualitycontrol programs. ${ }^{147}$

As mentioned, reflex testing can reduce the time to initiating targeted treatment. ${ }^{82,85}$ Indeed, the reliance solely on clinician judgment decreases the likelihood of full adherence to testing guidelines. ${ }^{118}$ For example, in one study, only $21 \%$ of patients had biomarker test results available at the time of the oncology consultation, leading to significant delays in treatment initiation. ${ }^{122}$ Moreover, $19 \%$ of patients (eligible for targeted therapy) started firstline chemotherapy before biomarker results became available. Avoiding the need for clinicians to specify each biomarker test, through a testing policy that groups tests as a set of common requests, could help ensure testing occurs consistently and rapidly. ${ }^{122}$

Poor cooperation between pathology and molecular testing laboratories has been cited as a potential barrier to biomarker testing. ${ }^{128}$ With rapid progress in the molecular profiling of NSCLC and its increasing complexity, collaboration and frequent communication between clinicians obtaining tumor samples, oncologists and pathologists (ie a multidisciplinary team) are essential to successful and timely biomarker testing. Although the ideal approach will vary by country and region, the multidisciplinary team should endeavor to create a center-specific diagnostic and therapeutic plan. ${ }^{148}$ The pathologist's input is fundamental to ensure that the appropriate collection method will be used and that sufficient tissue will be collected to allow for morphological, IHC and molecular studies to be conducted. ${ }^{6}$ Collectively, the multidisciplinary team should provide individual centers with "stewardship" regarding tissue collection and biomarker testing. ${ }^{149}$

Although many barriers to successful biomarker testing exist at institutional and regional levels, initiatives are often necessary at the individual level. Knowledge translation in this area has demonstrated significant improvements in specialist understanding about tissue sampling, molecular testing and treatment in lung cancer. ${ }^{150}$ Furthermore, education of clinicians involved in obtaining diagnostic tumor specimens and reporting pathologists can increase the likelihood of reporting biomarker results by the time of initial oncology assessment. ${ }^{122}$ Wherever possible, approaching and educating individuals involved in lung cancer diagnosis and molecular testing, including interventional radiologists, respiratory physicians, pathology technicians and pathologists, should be considered in the context of increasing biomarker testing rates. ${ }^{110}$

\section{Testing for EGFR Mutations and ALK Rearrangements: Experiences from South Korea, Russia, Turkey, Brazil, Mexico, Argentina and China}

Lack of medical and clinical infrastructure complicates the ability to collect country-specific statistics on incidence 
and prevalence of NSCLC, including standard practices and outcomes. However, the paucity of available data emphasizes the clear need to develop evidence and correct the "unbalance" of country-level information.

\section{South Korea}

Biomarker testing for $E G F R$ mutations is considered standard practice in South Korea, provided tissue samples are adequately collected. Both EGFR testing and EGFR TKIs are subsidized under the national reimbursement policy. Two real-time PCR-based assays, Cobas ${ }^{\circledR}$ EGFR Mutation Test v2 and PANAMutyper ${ }^{\mathrm{TM}}$ EGFR, have been approved by the Ministry of Food and Drug Safety (formerly known as the Korea FDA). The assays are also approved for ctDNA-based EGFR testing, and their use is evenly distributed between laboratories. Recently, a droplet digital PCR-based assay, the GenesWell ${ }^{\mathrm{TM}}$ ddEGFR Mutation Test, has been approved by the Ministry of Food and Drug Safety. All three methods are reimbursed in South Korea. Regarding the detection of $A L K$ rearrangements in patients with NSCLC, the Ventana $A L K$ (D5F3) assay was approved as a CDx by the Ministry of Food and Drug Safety in 2018. Most laboratories in South Korea have subsequently changed their method for $A L K$ testing from FISH to Ventana $A L K$ CDx D5F3. Both $A L K$ testing and ALK inhibitors are subsidized under the national reimbursement policy.

\section{Russia}

Improving the diagnosis of malignant neoplasms, particularly in patients with NSCLC, is a priority area for the modernization of cancer care in the Russian Federation. Clinical guidelines issued by the Russian Federation Ministry of Health advocate testing for mutations in the EGFR gene and $A L K$ and ROS1 translocations, enabling the administration of effective targeted therapy. However, in practice, molecular testing faces several challenges. First, testing requires highly qualified and experienced technicians. Four large laboratories based at national medical research centers are currently responsible for molecular testing, together with 30 reference laboratories supported by the Russian Society of Clinical Oncology. ${ }^{151}$ A second limitation is the transportation of samples from remote regions of the Russian Federation to suitably qualified laboratories. A federal project, titled "Fight against oncological diseases," is currently working to increase the number of reference laboratories, replace obsolete equipment and establish new laboratories in regional centers.

Biomarker testing for $E G F R$ mutations is predominantly conducted using the Cobas ${ }^{\circledR}$ EGFR Mutation Test v2 or Sanger sequencing. ${ }^{152}$ NGS is not used for routine testing due to its high cost. In most centers, IHC is used for the detection of $A L K$ rearrangements. However, the presence of artifacts, and $5-10 \%$ of doubtful cases, requires the use of alternative methods (eg FISH) for confirmation. ${ }^{146}$ At the time of writing, PCR-based methods for the identification of $A L K$ translocations have not been registered in the Russian Federation. The methods described above for the detection of $E G F R$ mutations and $A L K$ rearrangements are funded by the Obligatory Medical Insurance Fund.

\section{Turkey}

In Turkey, routine qPCR assessment of EGFR mutation status is conducted by most centers and is reimbursed by government-held healthcare insurance. Despite this, an insufficient amount of tumor cells in the biopsy specimen and poor tissue quality remain significant issues in approximately $5-25 \%$ of cases. ${ }^{136}$ FISH assessment of $A L K$ rearrangements is reimbursed for all patients with NSCLC. ${ }^{136}$ IHC is commonly used as a pre-screening method by most centers, with subsequent confirmation by FISH analysis. ${ }^{136}$ RT-PCR or NGS methods are used in cases where no signal can be obtained with FISH, or where there is discordance between IHC and FISH results. ${ }^{153}$

In $A L K+$ NSCLC patients treated with lorlatinib, oneyear OS rate was estimated at $65 \%$. In response-evaluable patients $(\mathrm{n}=55)$, the ORR and disease control rate were $68.6 \%$ and $87.0 \%$, respectively; $A L K+$ patient responses were $69.6 \%$ and $87.0 \%$, respectively. ${ }^{154}$ Patients receiving erlotinib therapy had significantly improved OS rates compared with patients who received non-TKI treatments (288 versus 119 weeks; $p=0.004)$, whereas PFS rates were not significantly different in patients who did and did not receive erlotinib ( $32 \pm 5$ versus $33 \pm 3$ weeks; $\mathrm{p}=0.755$ ). Patients expressing both EGFR and KRAS mutations reported the lowest OS rate. Erlotinib therapy was associated with increased survival in these patients. ${ }^{155}$

The overall frequency of all EGFR mutations in Turkish patients with NSCLC is estimated at over $16 \%,{ }^{156,157}$ with $32 \%$ and $20 \%$ of cases expressing exon 19 and 21 mutations, respectively. ${ }^{158}$ Frequency estimates were significantly higher in female patients and non-smokers. ${ }^{159}$ Following lung surgery, EGFR driver mutations have been reported in 
up to $40 \%$ of patients. ${ }^{160}$ Data from Turkish patients with Stage III NSCLC suggest neoadjuvant chemotherapy with three agents prior to surgery is associated with outcome benefits. ${ }^{161}$

\section{Brazil}

Although no formal surveys exist, an estimated $70 \%$ of all AdC NSCLC cases in Brazil undergo molecular testing. ${ }^{124,162,163}$ There are no national outcome or survival statistics, as local data collection is variable or simply not performed across several states. In addition, testing practices vary between centers: several laboratories have adopted reflex testing policies, whereas others approach molecular testing as an on-demand service. Similarly, some laboratories prefer NGS technologies, ${ }^{162-164}$ sequencing 14-20 genes at one time, ${ }^{124,162,165}$ whereas others have adopted strategies to improve TAT by using RT-PCR assays for $E G F R$ and BRAF mutations, ${ }^{162,164-166}$ and IHC/FISH for $A L K, \quad R O S 1$ and $P D-L 1$ rearrangements. ${ }^{163,164,167}$

In the absence of government reimbursement for molecular testing, several pharmaceutical companies have recently established a national "Lung Mapping" consortium. The consortium provides oncologists with access to a subsidized NGS-based test using the FoundationOne ${ }^{\circledR}$ platform and has considerably improved access to testing in several Brazilian centers. This ongoing project has yet to report national detection rates of important driver genes.

\section{Mexico}

In Mexico, lung cancer accounts for $10 \%$ of all cancerrelated mortality, ${ }^{168}$ and only $56.5 \%$ of NSCLC cases have a history of tobacco smoking, which suggests that other environmental factors such as hydrocarbons, metals, air pollution, and wood-smoke exposure could have a greater impact in the development of lung cancer. ${ }^{169,170}$ The prevalence of $E G F R$ mutations and $A L K$ rearrangements among patients with NSCLC has been estimated at $34.3 \%$ and $7.6 \%$, respectively. ${ }^{47,171}$

Approximately $90 \%$ of EGFR mutations are exon 19 deletions and L858R mutations in exon 21, although $20.5 \%$ of patients express rare mutations in exons 18-21. ${ }^{172}$ The most frequent EGFR mutations in patients from Mexico are Q787 (15.6\%), exon 19 deletions (11.1\%), L858R mutation in exon $21(7.8 \%)$, and T790M mutation in exon $20(1.1 \%)$. Other mutations have been identified, such as in KRAS, MET and PDGFRA (20\%), HNF1A (14.4\%), APC (12.2\%), HER2 (11.1\%), and MSH6
$(10 \%)$, as well as alterations of lower frequency in PIK3CA, GUSB, ALK rearrangements, KSR1, KIT, STK11, FLT3, ERBB4, VHL, NOTCH1, GNAS, FGFR3, $C D H 1, B R A F, A B L 1$ and $R B 1 .{ }^{173}$ In addition, the prevalence of $A L K$ rearranged NSCLC is estimated at $7.6 \%$ in Mexico. Although there is a country and continental variability of $A L K$ rearrangement frequency, the overall incidence of $A L K$ rearranged NSCLC in Latin America does not differ from the rest of the word. ${ }^{171}$

However, the uptake of molecular testing as part of the standard diagnostic pathway in NSCLC remains variable. Access to EGFR TKIs is restricted due to cost, and in turn, molecular testing for patients with NSCLC is not reimbursed by the healthcare system. Apart from several large diagnostic centers, such as the Instituto Nacional de Cancerología, very few laboratories have the financial means or adequate infrastructure to undertake testing on a regular basis. Current testing methods available in Mexico include FISH, RT-PCR and IHC. Unfortunately, the FISH test can be expensive, especially for low-income countries, requires experience for accurate interpretation, and does not identify specific fusion transcript variants. In some cases, pharmaceutical companies with novel molecular therapies will pay for the cost of genomic testing as a means of recruiting patients to clinical trials. Although these settings may help a subset of eligible patients in the short term, they benefit only a restricted number of patients and come with substantial burdens.

\section{Argentina}

Access to, and reimbursement of, molecular testing for patients with NSCLC remains a major issue in Argentina. Approximately $90 \%$ of all testing is concentrated in a handful of private laboratories and large academic centers in major cities. In general, molecular tests are ordered by the treating oncologists; testing following surgical resection is very infrequent (approximately $1 \%$ of all samples). However, reflex testing protocols are possible in large academic centers with dedicated pathology services. There are no comprehensive studies on patient access to testing. In larger centers, an estimated $60-80 \%$ of all patients with AdC NSCLC undergo molecular testing, whereas the average TAT for $E G F R / B R A F$ and $A L K /$ ROS1 tests is 5-7 days and 1-2 days, respectively. Depending on the type of test and the platform used, approximately $5-10 \%$ of cases are rejected due to inadequate samples. 
Molecular testing for NSCLC follows the IASLC and NCCN guidelines, whereby EGFR, BRAF, ALK and ROS1 are routinely assessed. Of all $E G F R$ mutations, uncommon EGFR mutations (excluding L858R and ex19del) are detected in $10-20 \%$ of cases. ${ }^{174}$ Cobas ${ }^{\circledR}$ EGFR Mutation Test $\mathrm{v} 2$ or Therascreen ${ }^{\circledR}$ qPCR is commonly used to assess $E G F R$ and BRAF mutations. IHC with the D5F3 Ventana IHC kit is used for the assessment of $A L K$, whereas ROS1 status is determined using the D4D6 signaling antibody. ROS1 IHC-positive cases are confirmed by FISH. NGS, such as the Oncomine Focus Assay for solid tumors, is available in a few laboratories. In the absence of reimbursement for clinical application, occasionally patients pay privately for the assay; however, the technique is more frequently used for research-based activities. Liquid biopsy is also available and frequently used in patients with resistance to EGFR TKIs. In some instances, it is ordered for firstline testing when the tissue sample is insufficient.

Analysis of clinical and pathologic data from two academic centers in Buenos Aires suggests that KRAS mutations occur in approximately $23 \%$ of patients with NSCLC, a higher frequency than that reported across Latin America. ${ }^{175}$ There was a higher proportion of male patients $(65 \%)$ and smoking history (94\%); mean patient age was 66 years (IQR: $61-72.5$ years). In total, 94\% of tumor histology samples were identified as adenocarcinoma. Of patients with metastatic disease, $90 \%$ received treatment. First-line treatment included chemotherapy (94\%) or immunotherapy (6\%). Subsequently, half of all patients received second-line treatment, of which $75 \%$ received immunotherapy. With a follow-up of 38 months, median OS of patients with metastatic disease was 14.2 months $(95 \%$ confidence interval $[\mathrm{CI}], 7.7-30.3) .{ }^{175}$

When considering uncommon EGFR mutations (other than L858R and exon 19 deletion), distribution of tumors comprised exon 18 G719X (46.7\%), exon 21 L861Q (24.4\%), exon 20 T790M (20\%), exon 20 S768I (11.1\%), exon 20 insertion (4.4\%), and exon 19 pLys745_Ala750del (2.2\%). ${ }^{174}$ Among patients included in the database review, the most frequent EGFR TKI regimen received was afatinib, followed by erlotinib/gefitinib, and osimertinib. Overall, $22 \%$ of tumors were considered complex, defined as $\geq 2$ coexisting and distinct EGFR mutations, and were associated with a significantly better response to first-line EGFR TKI (ORR 90\%) than those with single, non-resistant uncommon EGFR mutations (ORR 52\%) $(\mathrm{p}=0.06)$. Similarly, patients with complex mutations showed a better OS (median not reached versus 20.3 months [95\% CI, 8.7-31.9], respectively; $\mathrm{p}=0.04) .{ }^{174}$

Private and academic laboratories have different reimbursement systems. Approximately $90 \%$ of all molecular tests conducted by private laboratories are supported by the pharmaceutical industry. In academic hospitals, pharmaceutical support is more variable and often confined to the largest centers in Buenos Aires. In those institutions, approximately $50 \%$ of molecular tests receive pharmaceutical support, with the remaining tests supported by health insurance and/or privately paying patients. To date, establishing laboratories with the expertise to undertake molecular testing in regional healthcare facilities has been hampered by the absence of a clear and dedicated reimbursement system.

\section{China}

The National Medical Products Administration of China has approved genetic testing platforms for EGFR mutations, including PCR-based methods, Sanger sequencing, Luminex liquid chip and NGS. In China, not all hospitals have the ability or equipment to perform genetic testing and analysis, and so the frequency of EGFR testing for NSCLC varies between regions. In Northern China, Cheng et al reported a screening rate of $42.5 \% .{ }^{176}$ PCR-based methods, such as ARMS (72.1\%), Sanger sequencing $(5.36 \%)$ and Luminex liquid chip (5.10\%), were the most frequently used platforms. ${ }^{176}$ The median time from tumor diagnosis to $E G F R$ or $A L K$ status confirmation was 7 and 5 days, respectively. ${ }^{177}$

The efficacy of targeted therapies in NSCLC has been analyzed using a network meta-analysis of 128 clinical trials with 39,501 participants across 14 therapeutic groups. Compared with chemotherapy, ORR was significantly improved for afatinib, alectinib and crizotinib. Cabozantinib and alectinib showed the highest probability for first-line treatment ranking in ORR $(62.5 \%)$. ${ }^{178}$ Targeted therapies have varying effects on OS in NSCLC patients with different gene mutations. ${ }^{179-181}$ For example, Yang et al found that OS was increased in patients with EGFR exon 19 deletion compared with the exon 21 L858R point mutation (92 versus 65 months; $\mathrm{p}<0.001$ ). ${ }^{180}$ Compared with chemotherapy, ALK-targeted treatment was associated with a significantly higher PFS (hazard ratio $[\mathrm{HR}]=0.48 ; 95 \% \mathrm{CI}, 0.42-0.55)$, but not significantly higher $\mathrm{OS}(\mathrm{HR}=0.88 ; 95 \% \mathrm{CI}, 0.72-1.07)$ in five eligible studies $(\mathrm{n}=1404){ }^{181}$ 
Several centers in China have adopted reflex testing policies to help streamline the time between pathological diagnosis of NSCLC and identification of molecular markers. Once a sample is diagnosed as NSCLC, a second sample is prepared, and the process of DNA extraction/ molecular identification initiated. Using this process, the molecular report can be sent out at the same time as the routine pathology report. The typical driver genes detected include receptor tyrosine kinases (RTKS), EGFR, HER2, $D D R 2$ (mutation), $A L K, R O S 1, R E T$ (gene rearrangement), MET, FGFR1, PDGFRA (gene amplification), KRAS, BRAF, PIK3CA, and PTEN. ${ }^{182}$

In the case of lung biopsy specimens, unstained slices or wax rolls are pre-cut at the same time as the pathology sample. When staining or IHC results are indicative of NSCLC, the unstained slices or wax rolls are used for DNA extraction/molecular detection, and the molecular pathology report is available 1-2 days after routine diagnosis. Recent analyses of neoadjuvant targeted therapy suggest significant improvements in radiographic response rates compared with conventional chemotherapy regimens, resulting in longer disease-free survival in real-world settings. ${ }^{183,184}$

All countries indicated above are based on the experiences and perspectives of the authors in their respective countries.

\section{Conclusion}

In summary, the selection of patients with advanced NSCLC based on their EGFR and $A L K$ status is vital, on account of the high response rates observed with the EGFR- and ALK-targeted agents. Despite this, the uptake of biomarker testing varies substantially between countries, and the translation of guideline recommendations into clinical practice remains challenging. Inequitable access to targeted therapies and the absence of reimbursement for biomarker testing are commonly cited as barriers to uptake. Tissue sample quality, delayed TAT and the accurate interpretation of test results create additional barriers. Strategies to address these issues will necessarily be context- and country-dependent but could include the development of multidisciplinary tumor boards to ensure tissue and testing stewardship, standard operating procedures (SOPs) for routine biomarker screening in newly diagnosed patients and further education of specialists who obtain diagnostic cancer specimens.

\section{Clinical Practice Points}

\section{Clinical Governance}

- Close working relationships between physicians obtaining tumor samples, oncologists and pathologists are essential, and where possible, multidisciplinary tumor boards should be considered to optimize the diagnosis and treatment of lung cancer.

- Center-specific SOPs should be established as part of routine clinical practice to streamline the NSCLC diagnostic pathway.

Infrastructure and Quality Control

- From a laboratory perspective, adequate infrastructure and staffing are necessary to facilitate rapid TAT for biomarker testing.

- Quality control is essential to ensure consistent and reliable diagnostic results. All laboratories that undertake biomarker testing should participate in external quality assessment programs.

Education

- Guidance and education of physicians involved in diagnostic tumor specimens and reporting can increase the likelihood of reporting biomarker test results by the time of the initial oncology consultation.

\section{Biomarker Testing}

- Biomarker testing is necessary for determining the optimal treatment of patients newly diagnosed with NSCLC. Biomarker testing for EGFR mutation, $A L K$ and ROS1 rearrangements, $B R A F$ mutation and $P D-L 1$ should be initiated as soon as a pathological diagnosis on non-SCC NSCLC is confirmed (or SCC NSCLC, in selected cases).

- If NGS is available, alterations in genes such as RET, MET, HER2 and KRAS should also be assessed.

- Reflex biomarker testing at the level of the pathologist should be part of SOPs for confirmed non-SCC NSCLC. This bypasses the time delay for oncology consultation and allows prioritization of sample processing for biomarker testing.

- Timely feedback from pathologists to clinicians acquiring lung cancer diagnostic samples regarding sample adequacy is important. 
- Sanger sequencing, pyrosequencing, real-time PCR, and NGS are recommended for EGFR testing, and validated tests, including FISH and IHC, may be used for $A L K$ testing. NGS can result in a dramatic reduction in cost and should be considered as a means of addressing the financial burden associated with biomarker testing.

- Repeat biomarker testing at the time of disease progression is recommended to identify EGFR- and $A L K$ resistance targets.

\section{Acknowledgments}

Medical writing support and editorial assistance were provided by Brad Dalton, MSc, on behalf of Synergy Vision Ltd, London, according to Good Publication Practice guidelines, and were funded by Takeda Pharmaceuticals International AG - Singapore Branch.

\section{Disclosure}

MD reports personal fees, non-financial support for speaker honoraria and/or congress travel assistance from Pfizer, Takeda, and Roche, outside the submitted work. AA and HW are employees of Takeda Pharmaceuticals International AG - Singapore Branch. The authors report no other conflicts of interest in this work.

\section{References}

1. Barta JA, Powell CA, Wisnivesky JP. Global epidemiology of lung cancer. Ann Glob Health. 2019;85(1):8. doi:10.5334/aogh.2419.

2. Bray F, Ferlay J, Soerjomataram I, Siegel RL, Torre LA, Jemal A. Global cancer statistics 2018: GLOBOCAN estimates of incidence and mortality worldwide for 36 cancers in 185 countries. CA Cancer $J$ Clin. 2018;68(6):394-424. doi:10.3322/caac. 21492

3. Inamura K. Update on immunohistochemistry for the diagnosis of lung cancer. Cancers (Basel). 2018;10(3):72. doi:10.3390/cancers 10030072

4. International Agency for Research on Cancer (IARC) and World Health Organisation (WHO). Global cancer observatory. Available from: https://gco.iarc.fr/. Accessed July 15, 2021.

5. Goss PE, Strasser-Weippl K, Lee-Bychkovsky BL, et al. Challenges to effective cancer control in China, India, and Russia. Lancet Oncol. 2014;15(5):489-538. doi:10.1016/S1470-2045(14)70029-4

6. Travis WD, Brambilla E, Noguchi M, et al. International Association for the Study of Lung Cancer/American Thoracic Society/European Respiratory Society international multidisciplinary classification of lung adenocarcinoma. $J$ Thorac Oncol. 2011;6(2):244-285. doi:10.1097/JTO.0b013e318206a221

7. Devesa SS, Bray F, Vizcaino AP, Parkin DM. International lung cancer trends by histologic type: male:female differences diminishing and adenocarcinoma rates rising. Int $J$ Cancer. 2005;117(2):294-299. doi:10.1002/ijc. 21183

8. Darling HS, Viswanath S, Singh R, et al. A clinico-epidemiological, pathological, and molecular study of lung cancer in Northwestern India. J Cancer Res Ther. 2020;16(4):771-779. doi:10.4103/jcrt. JCRT_473_17

9. Chen Z, Fillmore CM, Hammerman PS, Kim CF, Wong KK. Nonsmall-cell lung cancers: a heterogeneous set of diseases. Nat Rev Cancer. 2014;14(8):535-546. doi:10.1038/nrc3775
10. Planchard D, Popat S, Kerr K, et al. Metastatic non-small cell lung cancer: ESMO Clinical Practice Guidelines for diagnosis, treatment and follow-up. Ann Oncol. 2018;29(4_suppl):iv192iv237. doi:10.1093/annonc/mdy275

11. Paez JG, Janne PA, Lee JC, et al. EGFR mutations in lung cancer: correlation with clinical response to gefitinib therapy. Science. 2004;304(5676):1497-1500. doi:10.1126/science.1099314

12. Mazieres J, Zalcman G, Crino L, et al. Crizotinib therapy for advanced lung adenocarcinoma and a ROS1 rearrangement: results from the EUROS1 cohort. $J$ Clin Oncol. 2015;33 (9):992-999. doi:10.1200/JCO.2014.58.3302

13. McDermott U, Iafrate AJ, Gray NS, et al. Genomic alterations of anaplastic lymphoma kinase may sensitize tumors to anaplastic lymphoma kinase inhibitors. Cancer Res. 2008;68(9):3389-3395. doi:10.1158/0008-5472.CAN-07-6186

14. Ettinger DS, Aisner DL, Wood DE, et al. NCCN guidelines insights: non-small cell lung cancer, version 5.2018. J Natl Compr Canc Netw. 2018;16(7):807-821. doi:10.6004/ jnccn.2018.0062

15. Wu YL, Planchard D, Lu S, et al. Pan-Asian adapted Clinical Practice Guidelines for the management of patients with metastatic non-small-cell lung cancer: a CSCO-ESMO initiative endorsed by JSMO, KSMO, MOS, SSO and TOS. Ann Oncol. 2019;30(2):171-210. doi:10.1093/annonc/mdy554

16. Solomon B. First-line treatment options for ALK-rearranged lung cancer. Lancet. 2017;389(10072):884-886. doi:10.1016/S01406736(17)30124-1

17. Prabhash K, Advani SH, Batra U, et al. Biomarkers in non-small cell lung cancers: Indian consensus guidelines for molecular testing. Adv Ther. 2019;36(4):766-785. doi:10.1007/s12325-01900903-y

18. Chan DLH, Toh GLX, Goh LL. Clinical implementation of plasma EGFR T790M testing using droplet digital PCR in TKIresistant NSCLC patients. Exp Mol Pathol. 2020;116:104515. doi:10.1016/j.yexmp.2020.104515

19. Yoneda K, Imanishi N, Ichiki Y, Tanaka F. Treatment of nonsmall cell lung cancer with EGFR-mutations. J UOEH. 2019;41 (2):153-163. doi:10.7888/juoeh.41.153

20. Remon J, Hendriks LEL, Cardona AF, Besse B. EGFR exon 20 insertions in advanced non-small cell lung cancer: a new history begins. Cancer Treat Rev. 2020;90:102105. doi:10.1016/j. ctrv.2020.102105

21. Brown AL, Li M, Goncearenco A, Panchenko AR, Nussinov R. Finding driver mutations in cancer: elucidating the role of background mutational processes. PLoS Comput Biol. 2019;15(4): e1006981. doi:10.1371/journal.pcbi.1006981

22. Tsao AS, Scagliotti GV, Bunn PA, et al. Scientific advances in lung cancer 2015. $J$ Thorac Oncol. 2016;11(5):613-638. doi:10.1016/j.jtho.2016.03.012

23. Shim HS, Choi YL, Kim L, et al. Molecular testing of lung cancers. J Pathol Transl Med. 2017;51(3):242-254. doi:10.4132/ jptm.2017.04.10

24. Soda M, Choi YL, Enomoto M, et al. Identification of the transforming EML4-ALK fusion gene in non-small-cell lung cancer. Nature. 2007;448(7153):561-566. doi:10.1038/nature05945

25. Lee JK, Kim TM, Koh Y, et al. Differential sensitivities to tyrosine kinase inhibitors in NSCLC harboring EGFR mutation and ALK translocation. Lung Cancer. 2012;77(2):460-463. doi:10.1016/j.lungcan.2012.04.012

26. Lee T, Lee B, Choi YL, Han J, Ahn MJ, Um SW. Non-small cell lung cancer with concomitant EGFR, KRAS, and ALK mutation: clinicopathologic features of 12 cases. J Pathol Transl Med. 2016;50(3):197-203. doi:10.4132/jptm.2016.03.09

27. Mao Y, Wu S. ALK and ROS1 concurrent with EGFR mutation in patients with lung adenocarcinoma. Onco Targets Ther. 2017;10:3399-3404. doi:10.2147/OTT.S133349 
28. Schmid S, Gautschi O, Rothschild S, et al. Clinical outcome of ALK-positive non-small cell lung cancer (NSCLC) patients with de novo EGFR or KRAS co-mutations receiving tyrosine kinase inhibitors (TKIs). J Thorac Oncol. 2017;12(4):681-688. doi:10.1016/j.jtho.2016.12.003

29. Yang JJ, Zhang XC, Su J, et al. Lung cancers with concomitant EGFR mutations and ALK rearrangements: diverse responses to EGFR-TKI and crizotinib in relation to diverse receptors phosphorylation. Clin Cancer Res. 2014;20(5):1383-1392. doi:10.1158/1078-0432.CCR-13-0699

30. Yokoyama A, Tamura A, Miyakawa K, et al. Pulmonary adenocarcinoma, harboring both an EGFR mutation and ALK rearrangement, presenting a stable disease to erlotinib and a partial response to alectinib. Intern Med. 2018;57(16):2377-2382. doi:10.2169/internalmedicine.0383-17

31. Sharma SV, Bell DW, Settleman J, Haber DA. Epidermal growth factor receptor mutations in lung cancer. Nat Rev Cancer. 2007;7 (3):169-181. doi:10.1038/nrc2088

32. Imamura F, Kimura M, Yano Y, et al. Real-world osimertinib for EGFR mutation-positive non-small-cell lung cancer with acquired T790M mutation. Future Oncol. 2020;16(21):1537-1547. doi:10.2217/fon-2020-0203

33. van Veggel B, Madeira R Santos JFV, Hashemi SMS, et al. Osimertinib treatment for patients with EGFR exon 20 mutation positive non-small cell lung cancer. Lung Cancer. 2020;141:9-13. doi:10.1016/j.lungcan.2019.12.013

34. Piotrowska Z, Wang Y, Sequist LV, Ramalingam SS. ECOGACRIN 5162: a phase II study of osimertinib $160 \mathrm{mg}$ in NSCLC with EGFR exon 20 insertions. J Clin Oncol. 2020;38 (15_suppl):9513. doi:10.1200/JCO.2020.38.15_suppl.9513

35. Rybrevant. Prescribing Information. Janssen Biotech, Inc; 2021.

36. Sabari JK, Shu CA, Park K, et al. OA04.04 Amivantamab in postplatinum EGFR exon 20 insertion mutant non-small cell lung cancer. Presentation presented at World Conference on Lung Cancer 2020; January 28-31, 2021; Singapore.

37. Sabari JK, Shu CA, Park K, et al. OA04.04 Amivantamab in postplatinum EGFR exon 20 insertion mutant non-small cell lung cancer. J Thorac Oncol. 2021;16(3):S108-S109. doi:10.1016/j. jtho.2021.01.284

38. Ramalingam SS, Zhou C, Kim TM, et al. Mobocertinib (TAK788 ) in EGFR exon 20 insertion (ex20ins)+ metastatic NSCLC (mNSCLC): additional results from platinum-pretreated patients (pts) and EXCLAIM cohort of Phase 1/2 study. $J$ Clin Oncol. 2021;39(15_suppl):9014. doi:10.1200/ JCO.2021.39.15_suppl.9014

39. Ramalingam SS, Zhou C, Kim TM, et al. Mobocertinib (TAK788 ) in EGFR exon 20 insertion (ex20ins)+ metastatic NSCLC (mNSCLC): additional results from platinum-pretreated patients (pts) and EXCLAIM cohort of phase 1/2 study. Poster presented at the 57th Annual Meeting (Virtual) of the American Society of Clinical Oncology (ASCO); June 4-8, 2021.

40. Boch C, Kollmeier J, Roth A, et al. The frequency of EGFR and KRAS mutations in non-small cell lung cancer (NSCLC): routine screening data for central Europe from a cohort study. BMJ Open. 2013;3(4):e002560. doi:10.1136/bmjopen-2013-002560

41. Cote ML, Haddad R, Edwards DJ, et al. Frequency and type of epidermal growth factor receptor mutations in African Americans with non-small cell lung cancer. $J$ Thorac Oncol. 2011;6(3):627630. doi:10.1097/JTO.0b013e31820a0ec0

42. Ess SM, Herrmann C, Frick H, et al. Epidermal growth factor receptor and anaplastic lymphoma kinase testing and mutation prevalence in patients with advanced non-small cell lung cancer in Switzerland: a comprehensive evaluation of real world practices. Eur J Cancer Care (Engl). 2017;26(6):e12721. doi:10.1111/ ecc. 12721
43. Graham RP, Treece AL, Lindeman NI, et al. Worldwide frequency of commonly detected EGFR mutations. Arch Pathol Lab Med. 2018;142(2):163-167. doi:10.5858/arpa.2016-0579-CP

44. Midha A, Dearden S, McCormack R. EGFR mutation incidence in non-small-cell lung cancer of adenocarcinoma histology: a systematic review and global map by ethnicity (mutMapII). Am J Cancer Res. 2015;5(9):2892-2911.

45. Rosell R, Moran T, Queralt C, et al. Screening for epidermal growth factor receptor mutations in lung cancer. $N$ Engl J Med. 2009;361(10):958-967. doi:10.1056/NEJMoa0904554

46. Cheng H, Hosgood HD, Deng L, et al. Survival disparities in black patients with EGFR-mutated non-small-cell lung cancer. Clin Lung Cancer. 2020;21(2):177-185. doi:10.1016/j.cllc.2019.07.003

47. Arrieta O, Cardona AF, Martin C, et al. Updated frequency of EGFR and KRAS mutations in nonsmall-cell lung cancer in Latin America: the Latin-American Consortium for the Investigation of Lung Cancer (CLICaP). J Thorac Oncol. 2015;10(5):838-843. doi:10.1097/JTO.0000000000000481

48. Sequist LV, Waltman BA, Dias-Santagata D, et al. Genotypic and histological evolution of lung cancers acquiring resistance to EGFR inhibitors. Sci Transl Med. 2011;3(75):75ra26. doi:10.1126/scitranslmed.3002003

49. Yu HA, Arcila ME, Rekhtman N, et al. Analysis of tumor specimens at the time of acquired resistance to EGFR-TKI therapy in 155 patients with EGFR-mutant lung cancers. Clin Cancer Res. 2013;19(8):2240-2247. doi:10.1158/1078-0432. CCR-12-2246

50. Hata AN, Niederst MJ, Archibald HL, et al. Tumor cells can follow distinct evolutionary paths to become resistant to epidermal growth factor receptor inhibition. Nat Med. 2016;22(3):262269. doi:10.1038/nm.4040

51. Inukai M, Toyooka S, Ito S, et al. Presence of epidermal growth factor receptor gene T790M mutation as a minor clone in nonsmall cell lung cancer. Cancer Res. 2006;66(16):7854-7858. doi:10.1158/0008-5472.CAN-06-1951

52. Su KY, Chen HY, Li KC, et al. Pretreatment epidermal growth factor receptor (EGFR) T790M mutation predicts shorter EGFR tyrosine kinase inhibitor response duration in patients with nonsmall-cell lung cancer. J Clin Oncol. 2012;30(4):433-440. doi:10.1200/JCO.2011.38.3224

53. Santoni-Rugiu E, Melchior LC, Urbanska EM, et al. Intrinsic resistance to EGFR-tyrosine kinase inhibitors in EGFR-mutant non-small cell lung cancer: differences and similarities with acquired resistance. Cancers (Basel). 2019;11(7):923. doi:10.3390/cancers11070923

54. Ballard P, Yates JW, Yang Z, et al. Preclinical comparison of osimertinib with other EGFR-TKIs in EGFR-mutant NSCLC brain metastases models, and early evidence of clinical brain metastases activity. Clin Cancer Res. 2016;22(20):5130-5140. doi:10.1158/1078-0432.CCR-16-0399

55. Goss G, Tsai CM, Shepherd FA, et al. Osimertinib for pretreated EGFR Thr790Met-positive advanced non-small-cell lung cancer (AURA2): a multicentre, open-label, single-arm, phase 2 study. Lancet Oncol. 2016;17(12):1643-1652. doi:10.1016/S1470-2045 (16)30508-3

56. Janne PA, Yang JC, Kim DW, et al. AZD9291 in EGFR inhibitorresistant non-small-cell lung cancer. $N$ Engl J Med. 2015;372 (18):1689-1699. doi:10.1056/NEJMoa1411817

57. Sequist LV, Soria JC, Goldman JW, et al. Rociletinib in EGFRmutated non-small-cell lung cancer. $N$ Engl J Med. 2015;372 (18):1700-1709. doi:10.1056/NEJMoa1413654

58. Yang JC, Ahn MJ, Kim DW, et al. Osimertinib in pretreated T790M-positive advanced non-small-cell lung cancer: AURA study phase II extension component. J Clin Oncol. 2017;35 (12):1288-1296. doi:10.1200/JCO.2016.70.3223 
59. Nadler E, Pavilack M, Espirito JL, Clark J, Fernandes A. Observational study of treatment patterns in patients with epidermal growth factor receptor (EGFR) mutation-positive non-small cell lung cancer after first-line EGFR-tyrosine kinase inhibitors. Adv Ther. 2020;37(2):946-954. doi:10.1007/s12325-020-01221-4

60. Choi YL, Takeuchi K, Soda M, et al. Identification of novel isoforms of the EML4-ALK transforming gene in non-small cell lung cancer. Cancer Res. 2008;68(13):4971-4976. doi:10.1158/ 0008-5472.CAN-07-6158

61. Hallberg B, Palmer RH. Mechanistic insight into ALK receptor tyrosine kinase in human cancer biology. Nat Rev Cancer. 2013;13(10):685-700. doi:10.1038/nrc3580

62. Martelli MP, Sozzi G, Hernandez L, et al. EML4-ALK rearrangement in non-small cell lung cancer and non-tumor lung tissues. Am J Pathol. 2009;174(2):661-670. doi:10.2353/ ajpath.2009.080755

63. Perner S, Wagner PL, Demichelis F, et al. EML4-ALK fusion lung cancer: a rare acquired event. Neoplasia. 2008;10(3):298302. doi: $10.1593 /$ neo.07878

64. Rikova K, Guo A, Zeng Q, et al. Global survey of phosphotyrosine signaling identifies oncogenic kinases in lung cancer. Cell. 2007;131(6):1190-1203. doi:10.1016/j.cell.2007.11.025

65. Barlesi F, Mazieres J, Merlio JP, et al. Routine molecular profiling of patients with advanced non-small-cell lung cancer: results of a 1-year nationwide programme of the French Cooperative Thoracic Intergroup (IFCT). Lancet. 2016;387(10026):14151426. doi:10.1016/S0140-6736(16)00004-0

66. Chaft JE, Arcila ME, Paik PK, et al. Coexistence of PIK3CA and other oncogene mutations in lung adenocarcinoma-rationale for comprehensive mutation profiling. Mol Cancer Ther. 2012;11 (2):485-491. doi:10.1158/1535-7163.MCT-11-0692

67. Yang P, Kulig K, Boland JM, et al. Worse disease-free survival in never-smokers with ALK+ lung adenocarcinoma. $J$ Thorac Oncol. 2012;7(1):90-97. doi:10.1097/JTO.0b013e31823c5c32

68. Awad MM, Shaw AT. ALK inhibitors in non-small cell lung cancer: crizotinib and beyond. Clin Adv Hematol Oncol. 2014;12(7):429-439.

69. Friboulet L, Li N, Katayama R, et al. The ALK inhibitor ceritinib overcomes crizotinib resistance in non-small cell lung cancer. Cancer Discov. 2014;4(6):662-673. doi:10.1158/2159-8290.CD-13-0846

70. Kim DW, Tiseo M, Ahn MJ, et al. Brigatinib in patients with crizotinib-refractory anaplastic lymphoma kinase-positive nonsmall-cell lung cancer: a randomized, multicenter phase II trial. $J \quad$ Clin Oncol. 2017;35(22):2490-2498. doi:10.1200/ JCO.2016.71.5904

71. Kwak EL, Bang YJ, Camidge DR, et al. Anaplastic lymphoma kinase inhibition in non-small-cell lung cancer. $N$ Engl $J$ Med. 2010;363(18):1693-1703. doi:10.1056/NEJMoa1006448

72. Peters S, Camidge DR, Shaw AT, et al. Alectinib versus crizotinib in untreated ALK-positive non-small-cell lung cancer. $N$ Engl J Med. 2017;377(9):829-838. doi:10.1056/ NEJMoa1704795

73. Shaw AT, Kim DW, Nakagawa K, et al. Crizotinib versus chemotherapy in advanced ALK-positive lung cancer. $N$ Engl $J$ Med. 2013;368(25):2385-2394. doi:10.1056/NEJMoa1214886

74. Shaw AT, Solomon B. Targeting anaplastic lymphoma kinase in lung cancer. Clin Cancer Res. 2011;17(8):2081-2086. doi:10.1158/1078-0432.CCR-10-1591

75. Inamura $\mathrm{K}$, Takeuchi $\mathrm{K}$, Togashi $\mathrm{Y}$, et al. EML4-ALK lung cancers are characterized by rare other mutations, a TTF-1 cell lineage, an acinar histology, and young onset. Mod Pathol. 2009;22(4):508-515. doi:10.1038/modpathol.2009.2

76. Shaw AT, Yeap BY, Mino-Kenudson M, et al. Clinical features and outcome of patients with non-small-cell lung cancer who harbor EML4-ALK. J Clin Oncol. 2009;27(26):4247-4253. doi:10.1200/JCO.2009.22.6993
77. Sun Y, Ren Y, Fang Z, et al. Lung adenocarcinoma from East Asian never-smokers is a disease largely defined by targetable oncogenic mutant kinases. J Clin Oncol. 2010;28(30):4616-4620. doi:10.1200/JCO.2010.29.6038

78. Kim H, Park E, Kim YJ, Chung JH. ALK rearrangement in a pure squamous cell carcinoma: the challenge of detection of ALK rearrangement. Virchows Arch. 2013;462(5):597-599. doi:10.1007/s00428-013-1413-5

79. Rodig SJ, Mino-Kenudson M, Dacic S, et al. Unique clinicopathologic features characterize ALK-rearranged lung adenocarcinoma in the western population. Clin Cancer Res. 2009;15 (16):5216-5223. doi:10.1158/1078-0432.CCR-09-0802

80. Kalemkerian GP, Narula N, Kennedy EB, et al. Molecular testing guideline for the selection of patients with lung cancer for treatment with targeted tyrosine kinase inhibitors: American Society of Clinical Oncology endorsement of the College of American Pathologists/International Association for the Study of Lung Cancer/Association for Molecular Pathology Clinical Practice Guideline Update. J Clin Oncol. 2018;36(9):911-919. doi:10.1200/JCO.2017.76.7293

81. Lindeman NI, Cagle PT, Aisner DL, et al. Updated molecular testing guideline for the selection of lung cancer patients for treatment with targeted tyrosine kinase inhibitors: guideline from the College of American Pathologists, the International Association for the Study of Lung Cancer, and the Association for Molecular Pathology. Arch Pathol Lab Med. 2018;142 (3):321-346. doi:10.5858/arpa.2017-0388-CP

82. Cheema PK, Menjak IB, Winterton-Perks Z, et al. Impact of reflex EGFR/ ALK testing on time to treatment of patients with advanced nonsquamous non-small-cell lung cancer. $J$ Oncol Pract. 2017;13(2):e130-e138. doi:10.1200/JOP.2016.014019

83. Kim H, Shim HS, Kim L, et al. Guideline recommendations for testing of ALK gene rearrangement in lung cancer: a proposal of the Korean Cardiopulmonary Pathology Study Group. Korean J Pathol. 2014;48(1):1-9. doi:10.4132/ KoreanJPathol.2014.48.1.1

84. Inal C, Yilmaz E, Cheng H. Effect of reflex testing by pathologists on molecular testing rates in lung cancer patients: experience from a community-based academic center. J Clin Oncol. 2014;32 (15_Suppl):8098. doi:10.1200/jco.2014.32.15_suppl.8098

85. Miller TE, Yang M, Bajor D, et al. Clinical utility of reflex testing using focused next-generation sequencing for management of patients with advanced lung adenocarcinoma. J Clin Pathol. 2018;71(12):1108-1115. doi:10.1136/jclinpath-2018-205396

86. Hiley CT, Le Quesne J, Santis G, et al. Challenges in molecular testing in non-small-cell lung cancer patients with advanced disease. Lancet. 2016;388(10048):1002-1011. doi:10.1016/S01406736(16)31340-X

87. O’Donnell P, Ferguson J, Shyu J, et al. Analytic performance studies and clinical reproducibility of a real-time PCR assay for the detection of epidermal growth factor receptor gene mutations in formalin-fixed paraffin-embedded tissue specimens of nonsmall cell lung cancer. BMC Cancer. 2013;13:210. doi:10.1186/ 1471-2407-13-210

88. Schwartzberg L, Kim ES, Liu D, Schrag D. Precision oncology: who, how, what, when, and when not? Am Soc Clin Oncol Educ Book. 2017;37:160-169. doi:10.1200/EDBK_174176

89. Matsumoto S, Ikeda T, Zenke Y, et al. P89.06 Prospective concordance study of a multi-gene PCR assay and NGS for the detection of targetable gene alterations in lung cancer. $J$ Thorac Oncol. 2021;16(3):S690. doi:10.1016/j.jtho.2021.01.1271

90. Clavé S, Bellosillo B, Salido M, et al. P2.09-34 Next-generation sequencing implementation in non-small cell lung cancer molecular diagnosis. J Thorac Oncol. 2019;14(10):S783. doi:10.1016/ j.jtho.2019.08.1683 
91. Hwang I, Kim S, Chun S, Yoon S, Lee DH. P2.01-51 Nextgeneration sequencing for effective detection of various EGFR exon 20 insertions (E20ins) in non-small cell lung cancer (NSCLC). J Thorac Oncol. 2019;14(10):S659. doi:10.1016/j. jtho.2019.08.1394

92. Khoo C, Rogers TM, Fellowes A, Bell A, Fox S. Molecular methods for somatic mutation testing in lung adenocarcinoma: EGFR and beyond. Transl Lung Cancer Res. 2015;4(2):126-141. doi:10.3978/j.issn.2218-6751.2015.01.10

93. Provencio M, Pérez-Barrios C, Barquin M, et al. Next-generation sequencing for tumor mutation quantification using liquid biopsies. Clin Chem Lab Med. 2020;58(2):306-313. doi:10.1515/ cclm-2019-0745

94. Jiang J, Adams H-P, Yao L, et al. Concordance of genomic alterations by next-generation sequencing in tumor tissue versus cell-free DNA in stage I-IV non-small cell lung cancer. $J$ Mol Diagn. 2020;22(2):228-235. doi:10.1016/j. jmoldx.2019.10.013

95. Kechin A, Borobova V, Boyarskikh U, Khrapov E, Subbotin S, Filipenko M. NGS-PrimerPlex: high-throughput primer design for multiplex polymerase chain reactions. PLoS Comput Biol. 2020;16(12):e1008468. doi:10.1371/journal.pcbi.1008468

96. Bauml JM, Viteri S, Minchom A, et al. FP07.12 underdiagnosis of EGFR exon 20 insertion mutation variants: estimates from NGS-based real-world datasets. $J$ Thorac Oncol. 2021;16(3): S208-S209. doi:10.1016/j.jtho.2021.01.112

97. Zhao F, Xu M, Lei H, et al. Clinicopathological characteristics of patients with non-small-cell lung cancer who harbor EML4-ALK fusion gene: a meta-analysis. PLoS One. 2015;10(2):e0117333. doi:10.1371/journal.pone. 0117333

98. Mok TS, Carbone DP, Hirsch FR. IASLC Atlas of EGFR Testing in Lung Cancer. North Fort Myers, FL, USA: Editorial Rx Press; 2017.

99. Bruno R, Fontanini G. Next generation sequencing for gene fusion analysis in lung cancer: a literature review. Diagnostics (Basel). 2020;10(8):521. doi:10.3390/diagnostics10080521

100. Li RY, Liang ZY. Circulating tumor DNA in lung cancer: realtime monitoring of disease evolution and treatment response Chin Med $J$ (Engl). 2020;133(20):2476-2485. doi:10.1097/ CM9.0000000000001097

101. Scilla KA, Rolfo C. The role of circulating tumor DNA in lung cancer: mutational analysis, diagnosis, and surveillance now and into the future. Curr Treat Options Oncol. 2019;20(7):61. doi:10.1007/s11864-019-0653-2

102. Moding EJ, Diehn M, Wakelee HA. Circulating tumor DNA testing in advanced non-small cell lung cancer. Lung Cancer. 2018;119:42-47. doi:10.1016/j.lungcan.2018.02.019

103. Bernicker EH, Xiao Y, Abraham A, et al. Adherence to National Comprehensive Cancer Network ALK testing guidelines for patients with advanced non-small cell lung cancer in U.S. community medical centers. Oncologist. 2021;26(6):e1050-e1057. doi:10.1002/onco.13779

104. Niu X, Chuang JC, Berry GJ, Wakelee HA. Anaplastic lymphoma kinase testing: IHC vs. FISH vs. NGS. Curr Treat Options Oncol. 2017;18(12):71. doi:10.1007/s11864-017-0513-x

105. Tsao MS, Hirsch FR, Yatabe Y. IASLC Atlas of ALK and ROS1 Testing in Lung Cancer. North Fort Myers, FL: Editorial Rx Press; 2016.

106. United States Food and Drug Administration. VENTANA ALK (D5F3) CDx Assay - P140025. Available from: https://www. accessdata.fda.gov/scripts $/ \mathrm{cdrh} / \mathrm{cfdocs} / \mathrm{cfpma} / \mathrm{pma} . \mathrm{cfm} ? \mathrm{id}=$ P140025. Accessed July 15, 2021.

107. Conklin CM, Craddock KJ, Have C, Laskin J, Couture C, Ionescu $\mathrm{DN}$. Immunohistochemistry is a reliable screening tool for identification of ALK rearrangement in non-small-cell lung carcinoma and is antibody dependent. $J$ Thorac Oncol. 2013;8(1):45-51. doi:10.1097/JTO.0b013e318274a83e
108. Marchetti A, Ardizzoni A, Papotti M, et al. Recommendations for the analysis of ALK gene rearrangements in non-small-cell lung cancer: a consensus of the Italian Association of Medical Oncology and the Italian Society of Pathology and Cytopathology. J Thorac Oncol. 2013;8(3):352-358. doi:10.1097/JTO.0b013e31827d5280

109. Thunnissen E, Bubendorf L, Dietel M, et al. EML4-ALK testing in non-small cell carcinomas of the lung: a review with recommendations. Virchows Arch. 2012;461(3):245-257. doi:10.1007/ s00428-012-1281-4

110. Pennell NA, Mutebi A, Zhou Z-Y, et al. Economic impact of next generation sequencing vs sequential single-gene testing modalities to detect genomic alterations in metastatic non-small cell lung cancer using a decision analytic model. J Clin Oncol. 2018;36 (15 suppl):9031. doi:10.1200/JCO.2018.36.15 suppl.9031

111. Gray PN, Dunlop CL, Elliott AM. Not all next generation sequencing diagnostics are created equal: understanding the nuances of solid tumor assay design for somatic mutation detection. Cancers (Basel). 2015;7(3):1313-1332. doi:10.3390/cancers7030837

112. Pennell NA, Arcila ME, Gandara DR, West H. Biomarker testing for patients with advanced non-small cell lung cancer: real-world issues and tough choices. Am Soc Clin Oncol Educ Book. 2019;39:531-542. doi:10.1200/EDBK_237863

113. Solomon JP, Benayed R, Hechtman JF, Ladanyi M. Identifying patients with NTRK fusion cancer. Ann Oncol. 2019;30(8_suppl): viii16-viii22. doi:10.1093/annonc/mdz384

114. Benayed R, Offin M, Mullaney K, et al. High yield of RNA sequencing for targetable kinase fusions in lung adenocarcinomas with no mitogenic driver alteration detected by DNA sequencing and low tumor mutation burden. Clin Cancer Res. 2019;25 (15):4712-4722. doi:10.1158/1078-0432.CCR-19-0225

115. Davies KD, Le AT, Sheren J, et al. Comparison of molecular testing modalities for detection of ROS1 rearrangements in a cohort of positive patient samples. J Thorac Oncol. 2018;13 (10): 1474-1482. doi:10.1016/j.jtho.2018.05.041

116. Haynes BC, Blidner RA, Cardwell RD, et al. An integrated nextgeneration sequencing system for analyzing DNA mutations, gene fusions, and RNA expression in lung cancer. Transl Oncol. 2019;12(6):836-845. doi:10.1016/j.tranon.2019.02.012

117. Enewold L, Thomas A. Real-world patterns of EGFR testing and treatment with erlotinib for non-small cell lung cancer in the United States. PLoS One. 2016;11(6):e0156728. doi:10.1371/ journal.pone. 0156728

118. Gutierrez ME, Choi K, Lanman RB, et al. Genomic profiling of advanced non-small cell lung cancer in community settings: gaps and opportunities. Clin Lung Cancer. 2017;18(6):651-659. doi:10.1016/j.cllc.2017.04.004

119. Illei $\mathrm{PB}, \mathrm{Wong} \mathrm{W}, \mathrm{Wu} \mathrm{N}$, et al. ALK testing trends and patterns among community practices in the United States. JCO Precis Oncol. 2018;2:1-11. doi:10.1200/PO.18.00159

120. Isobe $\mathrm{H}$, Mori $\mathrm{K}$, Minato $\mathrm{K}$, et al. Real-world practice patterns for patients with advanced non-small cell lung cancer: multicenter retrospective cohort study in Japan. Lung Cancer (Auckl). 2017;8:191206. doi:10.2147/LCTT.S140491

121. Lee DH, Tsao MS, Kambartel KO, et al. Molecular testing and treatment patterns for patients with advanced non-small cell lung cancer: PIvOTAL observational study. PLoS One. 2018;13(8): e0202865. doi:10.1371/journal.pone.0202865

122. Lim C, Tsao MS, Le LW, et al. Biomarker testing and time to treatment decision in patients with advanced nonsmall-cell lung cancer. Ann Oncol. 2015;26(7):1415-1421. doi:10.1093/annonc/mdv208

123. MacLean E, Louder A, Saverno K, et al. Molecular testing patterns in metastatic non-small cell lung cancer. Am J Manag Care. 2016;22(2):e60-e67.

124. Palacio S, Pontes L, Prado E, et al. EGFR mutation testing: changing patterns of molecular testing in Brazil. Oncologist. 2019;24(4):e137-e141. doi:10.1634/theoncologist.2018-0254 
125. Pan IW, Mallick R, Dhanda R, Nadler E. Treatment patterns and outcomes in patients with non-squamous advanced non-small cell lung cancer receiving second-line treatment in a communitybased oncology network. Lung Cancer. 2013;82(3):469-476. doi:10.1016/j.lungcan.2013.09.018

126. Shen C, Kehl KL, Zhao B, Simon GR, Zhou S, Giordano SH. Utilization patterns and trends in epidermal growth factor receptor (EGFR) mutation testing among patients with newly diagnosed metastatic lung cancer. Clin Lung Cancer. 2017;18(4):e233-e241. doi:10.1016/j.cllc.2016.11.002

127. Sluga R, van den Borne BEEM, Roepman P, Peters BJM, Kastelijn EA, Schramel FMNH. Utilization of molecular testing and survival outcomes of treatment with first- or second-line tyrosine kinase inhibitors in advanced non-small cell lung cancer in a Dutch population. Anticancer Res. 2018;38(1):393-400. doi:10.21873/anticanres.12235

128. Yatabe Y, Kerr KM, Utomo A, et al. EGFR mutation testing practices within the Asia Pacific region: results of a multicenter diagnostic survey. $J$ Thorac Oncol. 2015;10(3):438-445. doi:10.1097/JTO.0000000000000422

129. Zhou Q, Song Y, Zhang X, et al. A multicenter survey of first-line treatment patterns and gene aberration test status of patients with unresectable Stage IIIB/IV nonsquamous non-small cell lung cancer in China (CTONG 1506). BMC Cancer. 2017;17(1):462. doi:10.1186/s12885-017-3451-x

130. Concentra and Cancer Research UK. Molecular diagnostic provision in the NHS in England for targeted cancer medicines (solid tumors) in the NHS. Concentra analytics. Available from: http:// www.cancerresearchuk.org/sites/default/files/policy_august2015_ mdx_final.pdf. Accessed July 15, 2021.

131. Hotta K, Kiura K, Tabata M, Takigawa N, Tanimoto M, Ueoka H. A survey of Japanese thoracic oncologists' perception of diagnostic and treatment strategies for EGFR mutant or EML4-ALK fusion non-small cell lung cancer. Chest. 2014;146(6):e222-e225. doi: $10.1378 /$ chest.14-2055

132. Jankovic R, Goncalves HJ, Cavic M, et al. LungCARD - report on worldwide research and clinical practices related to lung cancer. J BUON. 2019;24(1):11-19.

133. Peters M, Kim ES, Hirsch V. Clinical use of epidermal growth factor receptor testing in patients with advanced lung cancer by physicians: survey of US and international patterns. $J$ Glob Oncol. 2019;5:1-7. doi:10.1200/JGO.18.00057

134. Prabhash K, Parikh PM, Rajappa SJ, et al. Patterns of epidermal growth factor receptor testing across 111 tertiary care centers in India: result of a questionnaire-based survey. South Asian J Cancer. 2018;7(3):203-206. doi:10.4103/sajc. sajc_30_18

135. Schink JC, Trosman JR, Weldon CB, et al. Biomarker testing for breast, lung, and gastroesophageal cancers at NCI designated cancer centers. J Natl Cancer Inst. 2014;106(10):dju256. doi:10.1093/jnci/dju256.

136. Ryska A, Berzinec P, Brcic L, et al. NSCLC molecular testing in Central and Eastern European countries. BMC Cancer. 2018;18 (1):269. doi:10.1186/s12885-018-4023-4

137. Bar J, Cyjon A, Flex D, et al. EGFR mutation testing practice in advanced non-small cell lung cancer. Lung. 2014;192(5):759763. doi:10.1007/s00408-014-9604-7

138. Gobbini E, Galetta D, Tiseo M, et al. Molecular profiling in Italian patients with advanced non-small-cell lung cancer: an observational prospective study. Lung Cancer. 2017;111:30-37. doi:10.1016/j.lungcan.2017.06.009

139. McKeage MJ, Tin Tin S, Khwaounjoo P, et al. Screening for anaplastic lymphoma kinase (ALK) gene rearrangements in nonsmall-cell lung cancer in New Zealand. Intern Med J. 2020;50 (6):716-725. doi:10.1111/imj.14435
140. Smeltzer MP, Wynes MW, Lantuejoul S, et al. The International Association for the Study of Lung Cancer global survey on molecular testing in lung cancer. J Thorac Oncol. 2020;15 (9):1434-1448. doi:10.1016/j.jtho.2020.05.002

141. Chiang AC, Fernandes AW, Pavilack M, et al. EGFR mutation testing and treatment decisions in patients progressing on first- or second-generation epidermal growth factor receptor tyrosine kinase inhibitors. BMC Cancer. 2020;20(1):356. doi:10.1186/ s12885-020-06826-0

142. Larson KL, Huang B, Chen Q, et al. EGFR testing and erlotinib use in non-small cell lung cancer patients in Kentucky. PLoS One. 2020;15(8):e0237790. doi:10.1371/journal.pone.0237790

143. Ellis PM, Verma S, Sehdev S, Younus J, Leighl NB. Challenges to implementation of an epidermal growth factor receptor testing strategy for non-small-cell lung cancer in a publicly funded health care system. J Thorac Oncol. 2013;8(9):1136-1141. doi:10.1097/ JTO.0b013e31829f6a43

144. Raez LE, Santos ES, Rolfo C, et al. Challenges in facing the lung cancer epidemic and treating advanced disease in Latin America. Clin Lung Cancer. 2017;18(1):e71-e79. doi:10.1016/j. cllc.2016.05.003

145. Aye PS, Tin Tin S, McKeage MJ, Khwaounjoo P, Cavadino A, Elwood JM. Development and validation of a predictive model for estimating EGFR mutation probabilities in patients with nonsquamous non-small cell lung cancer in New Zealand. BMC Cancer. 2020;20(1):658. doi:10.1186/s12885-020-07162-z

146. Demidova I, Grinevich V, Avdalian A, et al. Detection of ALK rearrangements in 4002 Russian patients: the utility of different diagnostic approaches. Lung Cancer. 2017;103:17-23. doi:10.1016/j.lungcan.2016.11.001

147. Dietel M, Bubendorf L, Dingemans AM, et al. Diagnostic procedures for non-small-cell lung cancer (NSCLC): recommendations of the European Expert Group. Thorax. 2016;71(2):177-184. doi:10.1136/thoraxjnl-2014-206677

148. Bar J, Damianovich M, Hout Siloni G, et al. Genetic mutation screen in early non-small-cell lung cancer (NSCLC) specimens. Clin Lung Cancer. 2014;15(2):159-165. doi:10.1016/j. cllc.2013.11.005

149. Oxnard GR, Ritterhouse L. Best practices in incorporating biomarker testing to deliver precision therapy in cancer. Avaialble from: http://www.personalizedmedonc.com/article/precision-ther apy-in-cancer. Accessed Jul 15, 2021.

150. Zer A, Cutz JC, Sekhon H, et al. Translation of knowledge to practice-improving awareness in NSCLC molecular testing. $J$ Thorac Oncol. 2018;13(7):1004-1011. doi:10.1016/j. jtho.2018.03.005

151. Russian Society of Clinical Oncology. Practical recommendations of drug treatment: non-small cell lung cancer; 2019. Available from: https://rosoncoweb.ru/standarts/RUSSCO/. Accessed July $15,2021$.

152. Imyanitov EN, Demidova IA, Gordiev MG, et al. Distribution of EGFR mutations in 10,607 Russian patients with lung cancer. $\mathrm{Mol}$ Diagn Ther. 2016;20(4):401-406. doi:10.1007/s40291-016-0213-4

153. Letovanec I, Finn S, Zygoura P, et al. Evaluation of NGS and RTPCR methods for ALK rearrangement in European NSCLC patients: results from the European Thoracic Oncology Platform Lungscape Project. $J$ Thorac Oncol. 2018;13(3):413-425. doi:10.1016/j.jtho.2017.11.117

154. Kilickap S, Demirci U, Bugdayci F, et al. P1.14-15 Lorlatinib in ALK- or ROS1-positive non-small cell lung cancer patients: experience from an early access program in Turkey. $J$ Thorac Oncol. 2019;14(10):S558-S559. doi:10.1016/j.jtho.2019.08.1166

155. Demiray A, Yaren A, Karagenç N, et al. The frequency of EGFR and KRAS mutations in the Turkish population with non-small cell lung cancer and their response to erlotinib therapy. Balkan $J$ Med Genet. 2018;21(2):21-26. doi:10.2478/bjmg-2018-0022 
156. Güler Tezel G, Şener E, Aydın Ç, Önder S. Prevalence of epidermal growth factor receptor mutations in patients with nonsmall cell lung cancer in Turkish population. Balkan Med J. 2017;34(6):567-571. doi:10.4274/balkanmedj.2017.0297

157. Calibasi-Kocal G, Amirfallah A, Sever T, et al. EGFR mutation status in a series of Turkish non-small cell lung cancer patients. Biomed Rep. 2020;13(2):2. doi:10.3892/br.2020.1308

158. Bircan S, Baloglu H, Kucukodaci Z, Bircan A. EGFR and KRAS mutations in Turkish non-small cell lung cancer patients: a pilot study. Med Oncol. 2014;31(8):87. doi:10.1007/s12032-014-0087-4

159. Sag SO, Gorukmez O, Ture M, et al. Spectrum of EGFR gene mutations and ALK rearrangements in lung cancer patients in Turkey. Springerplus. 2016;5:482. doi:10.1186/s40064-016-2150-4

160. Demirağ F, Yılmaz A, Yılmaz Demirci N, Yılmaz Ü, Erdoğan Y. EGFR, KRAS, and BRAF mutational profiles of female patients with micropapillary predominant invasive lung adenocarcinoma. Turk J Med Sci. 2017;47(5):1354-1361. doi:10.3906/sag-1612150

161. Bozcuk H, Abali H, Coskun S. The correlates of benefit from neoadjuvant chemotherapy before surgery in non-small-cell lung cancer: a metaregression analysis. World J Surg Oncol. 2012;10 (1):161. doi:10.1186/1477-7819-10-161

162. Freitas HC, Torrezan GT, da Cunha IW, et al. Mutational portrait of lung adenocarcinoma in Brazilian patients: past, present, and future of molecular profiling in the clinic. Front Oncol. 2020;10:1068. doi:10.3389/fonc.2020.01068

163. Andreis TF, Correa BS, Vianna FS, et al. Analysis of predictive biomarkers in patients with lung adenocarcinoma from southern Brazil reveals a distinct profile from other regions of the country. J Glob Oncol. 2019;5:1-9. doi:10.1200/JGO.19.00174

164. Schluckebier L, Caetano R, Garay OU, et al. Cost-effectiveness analysis comparing companion diagnostic tests for EGFR, ALK, and ROS1 versus next-generation sequencing (NGS) in advanced adenocarcinoma lung cancer patients. BMC Cancer. 2020;20 (1):875. doi:10.1186/s12885-020-07240-2

165. Leal LF, de Paula FE, De Marchi P, et al. Mutational profile of Brazilian lung adenocarcinoma unveils association of EGFR mutations with high Asian ancestry and independent prognostic role of KRAS mutations. Sci Rep. 2019;9(1):3209. doi:10.1038/ s41598-019-39965-x

166. Carneiro JG, Couto PG, Bastos-Rodrigues L, et al. Spectrum of somatic EGFR, KRAS, BRAF, PTEN mutations and TTF-1 expression in Brazilian lung cancer patients. Genet Res (Camb). 2014;96:e02. doi:10.1017/S0016672314000032

167. Oliveira ACDSM, Silva AVAD, Alves M, et al. Molecular profile of non-small cell lung cancer in northeastern Brazil. J Bras Pneumol. 2019;45(3):e20180181. doi:10.1590/1806-3713/ e20180181

168. Arrieta O, Carmona A, Ramírez-Tirado LA, et al. Survival of patients with advanced non-small cell lung cancer enrolled in clinical trials. Oncology. 2016;91(4):185-193. doi:10.1159/ 000447404

169. Arrieta O, Campos-Parra AD, Zuloaga C, et al. Clinical and pathological characteristics, outcome and mutational profiles regarding non-small-cell lung cancer related to wood-smoke exposure. $J$ Thorac Oncol. 2012;7(8):1228-1234. doi:10.1097/ JTO.0b013e3182582a93

170. Soca-Chafre G, Hernández-Pedro N, Aviles-Salas A, et al. Targeted next generation sequencing identified a high frequency genetic mutated profile in wood smoke exposure-related lung adenocarcinoma patients. Oncotarget. 2018;9(55):30499-30512. doi:10.18632/oncotarget.25369

171. Arrieta O, Cardona AF, Bramuglia G, et al. Molecular epidemiology of ALK rearrangements in advanced lung adenocarcinoma in Latin America. Oncology. 2019;96(4):207-216. doi:10.1159/ 000493733
172. Arrieta O, Cardona AF, Federico Bramuglia G, et al. Genotyping nonsmall cell lung cancer (NSCLC) in Latin America. J Thorac Oncol. 2011;6(11):1955-1959. doi:10.1097/JTO.0b013e31822f655f

173. Hernández-Pedro N, Soca-Chafre G, Alaez-Versón C, et al. Mutational profile by targeted next generation sequencing of non-small cell lung cancer in the Mexican population. Salud Publica Mex. 2019;61(3):308-317. doi:10.21149/10113

174. Kaen D, Tsou F, Lupinacci L, et al. Outcomes of TKI treatment in patients with NSCLC harboring uncommon EGFR mutations: a real-world study in Argentina. J Thorac Oncol. 2021;16(3):S667S668. doi:10.1016/j.jtho.2021.01.1221

175. Blaquier J, Cerini M, Denninghoff V, et al. Prevalence, clinical characteristics and survival of patients with KRAS mutant lung cancer in Argentina. $J$ Thorac Oncol. 2021;16(3):S680. doi:10.1016/j.jtho.2021.01.1247

176. Cheng Y, Wang Y, Zhao J, et al. Real-world EGFR testing in patients with stage IIIB/IV non-small-cell lung cancer in North China: a multicenter, non-interventional study. Thorac Cancer. 2018;9(11):1461-1469. doi:10.1111/1759-7714.12859

177. Liang H, Song X, Zhang Y, et al. Real-world data on EGFR/ALK gene status and first-line targeted therapy rate in newly diagnosed advanced non-small cell lung cancer patients in Northern China: a prospective observational study. Thorac Cancer. 2019;10 (7):1521-1532. doi:10.1111/1759-7714.13090

178. Hoang T, Myung SK, Pham TT, Kim J, Ju W. Comparative efficacy of targeted therapies in patients with non-small cell lung cancer: a network meta-analysis of clinical trials. J Clin Med. 2020;9(4):1063. doi:10.3390/jcm9041063

179. Tang W, Li X, Xie X, et al. EGFR inhibitors as adjuvant therapy for resected non-small cell lung cancer harboring EGFR mutations. Lung Cancer. 2019;136:6-14. doi:10.1016/j. lungcan.2019.08.001

180. Yang W, Gao Y, Li X, et al. Postoperative survival of EGFR-TKItargeted therapy in non-small cell lung cancer patients with EGFR 19 or 21 mutations: a retrospective study. World J Surg Oncol. 2017;15(1):197. doi:10.1186/s12957-017-1251-z

181. Lee YC, Hsieh CC, Lee YL, Li CY. Which should be used first for ALK-positive non-small-cell lung cancer: chemotherapy or targeted therapy? A meta-analysis of five randomized trials. Medicina (Kaunas). 2019;55(2):29. doi:10.3390/ medicina55020029

182. Zhu QG, Zhang SM, Ding XX, He B, Zhang HQ. Driver genes in non-small cell lung cancer: characteristics, detection methods, and targeted therapies. Oncotarget. 2017;8(34):57680-57692. doi:10.18632/oncotarget.17016

183. Lv C, Ma Y, Feng Q, et al. Does neoadjuvant targeted therapy provide an opportunity for resectable EGFR-mutant lung cancer: a real-world retrospective study. $J$ Thorac Dis. 2020;12 (10):5324-5335. doi:10.21037/jtd-20-1265

184. Bao Y, Gu C, Xie H, et al. Comprehensive study of neoadjuvant targeted therapy for resectable non-small cell lung cancer. Ann Transl Med. 2021;9(6):493. doi:10.21037/atm-21-1134

185. Li Y, Zhang R, Peng R, et al. Reliability assurance of detection of EML4-ALK rearrangement in non-small cell lung cancer: the results of proficiency testing in China. J Thorac Oncol. 2016;11 (6):924-929. doi:10.1016/j.jtho.2016.03.004

186. Takeuchi K, Choi YL, Soda M, et al. Multiplex reverse transcription-PCR screening for EML4-ALK fusion transcripts. Clin Cancer Res. 2008;14(20):6618-6624. doi:10.1158/1078-0432. CCR-08-1018

187. Kerr KM. ALK testing in non-small cell lung carcinoma: what now? $J$ Thorac Oncol. 2014;9(5):593-595. doi:10.1097/ JTO.000000000000171

188. Savic S, Bubendorf L. Common fluorescence in situ hybridization applications in cytology. Arch Pathol Lab Med. 2016;140 (12):1323-1330. doi:10.5858/arpa.2016-0202-RA 
189. Sholl LM, Weremowicz S, Gray SW, et al. Combined use of ALK immunohistochemistry and FISH for optimal detection of ALKrearranged lung adenocarcinomas. J Thorac Oncol. 2013;8 (3):322-328. doi:10.1097/JTO.0b013e31827db604

190. von Laffert M, Warth A, Penzel R, et al. Multicenter immunohistochemical ALK-testing of non-small-cell lung cancer shows high concordance after harmonization of techniques and interpretation criteria. J Thorac Oncol. 2014;9(11):1685-1692. doi:10.1097/ JTO.0000000000000332
191. Wynes MW, Sholl LM, Dietel M, et al. An international interpretation study using the ALK IHC antibody D5F3 and a sensitive detection kit demonstrates high concordance between ALK IHC and ALK FISH and between evaluators. $J$ Thorac Oncol. 2014;9(5):631-638. doi:10.1097/JTO.0000000000000115

192. Rosenbaum JN, Bloom R, Forys JT, et al. Genomic heterogeneity of ALK fusion breakpoints in non-small-cell lung cancer. Mod Pathol. 2018;31(5):791-808. doi:10.1038/modpathol.2017.181

193. Lorbrena. Prescribing Information. Pfizer, Inc; 2021.

\section{Publish your work in this journal}

OncoTargets and Therapy is an international, peer-reviewed, open access journal focusing on the pathological basis of all cancers, potential targets for therapy and treatment protocols employed to improve the management of cancer patients. The journal also focuses on the impact of management programs and new therapeutic

Submit your manuscript here: https://www.dovepress.com/oncotargets-and-therapy-journal agents and protocols on patient perspectives such as quality of life, adherence and satisfaction. The manuscript management system is completely online and includes a very quick and fair peer-review system, which is all easy to use. Visit http://www.dovepress.com/ testimonials.php to read real quotes from published authors. 